\title{
Alpine grasslands with dominant Luzula alpinopilosa in the Julian and Carnic Alps (NW Slovenia, NE Italy)
}

\author{
Igor Dakskobler ${ }^{1} \&$ Livio Poldini ${ }^{2}$
}

Key words: phytosociology, synsystematics, Junco jacquiniiLuzuletum alpinopilosae, Juncetea trifidi, Julian Alps, Carnic Alps, Slovenia, Italy.

Ključne besede: fitocenologija, sinsistematika, Junco jacquiniiLuzuletum alpinopilosae, Juncetea trifidi, Julijske Alpe, Karnijske Alpe, Slovenija, Italija.

Received: 25. 4. 2018

Revision received: 31 . 10. 2018

Accepted: 12. 11. 2018

\begin{abstract}
We conducted a phytosociological study of alpine grasslands with dominant Luzula alpinopilosa in the Julian and Carnic Alps. Based on a comparison with similar communities elsewhere in the Alps we described a new association Junco jacquinii-Luzuletum alpinopilosae, which we classify into the provisional alliance Doronico glacialis-Juncion jacquinii, order Festucetalia spadiceae and class Juncetea trifidi. The new association characterises moist shady grasslands in gullies and on ledges on limestone admixed with marlstone and chert, in the elevation range between 2000 and $2500 \mathrm{~m}$, where the snow cover persists for extended periods. We distinguish three subassociations: -galietosum anisophyllae (the most calcareous form), -potentilletosum aureae (typical form) and-leucanthemopsietosum alpinae (acidophilic form on Werfen sandstones in the Carnic Alps, which is the most similar to the stands of the association Luzuletum alpinopilosae from the Central Alps).
\end{abstract}

Izvleček

Fitocenološko smo analizirali alpinska travišča v Julijskih in Karnijskih Alpah, v katerih prevladuje vrsta Luzula alpinopilosa. Na podlagi primerjave s podobnimi združbami drugod v Alpah smo opisali novo asociacijo Junco jacquiniiLuzuletum alpinopilosae, ki jo uvrščamo v provizorno novo zvezo Doronico glacialis-Juncion jacquinii, v red Festucetalia spadiceae in v razred Juncetea trifidi. Nova asociacija označuje vlažna osojna travišča v žlebovih in na policah na apnencu s primesjo laporovca in roženca, $v$ višinskem pasu od $2000 \mathrm{~m}$ do $2500 \mathrm{~m}$, kjer se dalj časa zadržuje sneg. Razlikujemo tri subasociacije: -galietosum anisophyllae (najbolj karbonatna oblika), -potentilletosum aureae (tipična oblika) in -leucanthemopsietosum alpinae (kisloljubna oblika na werfenskih peščenjakih v Karnijskih Alpah, ki je najbolj podobna sestojem asociacije Luzuletum alpinopilosae iz Centralnih Alp).

Dedicated to the late Professor Tone Wraber (1938-2010), on the occasion of his $80^{\text {th }}$ birthday

1 Scientific Research Centre of the Slovenian Academy of Sciences and Arts, Institute of Biology, Regional unit Tolmin, Brunov drevored 13, SI-5220 Tolmin, Slovenia. E-mail: Igor.Dakskobler@zrc-sazu.si.

2 Department of Life Sciences, University of Trieste, via L. Giorgieri, 5, I-34127 Trieste, Italy. E-mail: poldini@units.it 


\section{Introduction}

Luzula alpinopilosa is a southwestern-European montane species, a character species of the class Salicetea herbaceae (Aeschimann et al. 2004b: 754). In Slovenia it is distributed only in the Julian Alps (Figure 1), at the elevation range between $1695 \mathrm{~m}$ (Spodnji Lepoč above the Bala valley) and $2500 \mathrm{~m}$ (Mt. Mangart). It occurs mainly on shady, gentle to very steep alpine grasslands, in snow beds with dominating Salix herbacea, in tall herb communities, rarely also in alpine heaths. The parent material in these localities is usually mixed; limestone is admixed with marlstone, claystone or chert. So far, it has been recorded in the stands of associations Salicetum herbaceae s. lat., Luzuletum alpinopilosae s. lat. (= Luzuletum spadiceae s.lat.), Caricetum ferrugineae s. lat., Aconito-Peucedanetum ostruthii, Homogyno alpinae-Vaccinietum gaultherioidis, Gentiano pumilae-Salicetum serpillifoliae, Salicetum retuso-reticulatae, Caricetum curvulae s. lat., Carici curvulae-Nardetum, Calamagrostietum villosae nom. prov. (Festuca nigrescensCalamagrostis villosa ass. prov.) - mostly unpublished rele- vés by Tone Wraber and Igor Dakskobler in the FloVegSi database (Seliškar et al. 2003). Its occurrence in snow bed communities with Salix herbacea and an abundant moss layer is discussed in another article (Martinčič et al. 2019), whereas this paper focuses on the phytosociological analysis of alpine grasslands with dominating Luzula alpinopilosa that we found under Mt. Mangart (mainly on the extensive grasslands of Jarečica) and on shady slopes of Mts. Skutnik (Sončni Jelenk), Zadnji Pelc, Plešivec and Bedinji Vrh, at the elevations ranging from 2050 to $2500 \mathrm{~m}$, and observed from afar also elsewhere on the ledges and prominences of the rock wall of Loška Stena. We made 15 relevés. Slightly similar stands with dominating Luzula alpinopilosa were recorded at the elevations from 2000 to $2400 \mathrm{~m}$ in the Carnic Alps (Friuli Venezia Giulia) and provisionally classified into the association Luzuletum alpino-pilosae Br.-Bl. in Br--Bl. et Jenny 1926 (Poldini \& Vidali 1995: 167). In this autonomous region in the northeast of Italy, this species occurs more frequently than in Slovenia (Poldini 2002: 303). It was recorded also in the stands of associations Salicetum retuso-reticulatae, Sieversio-

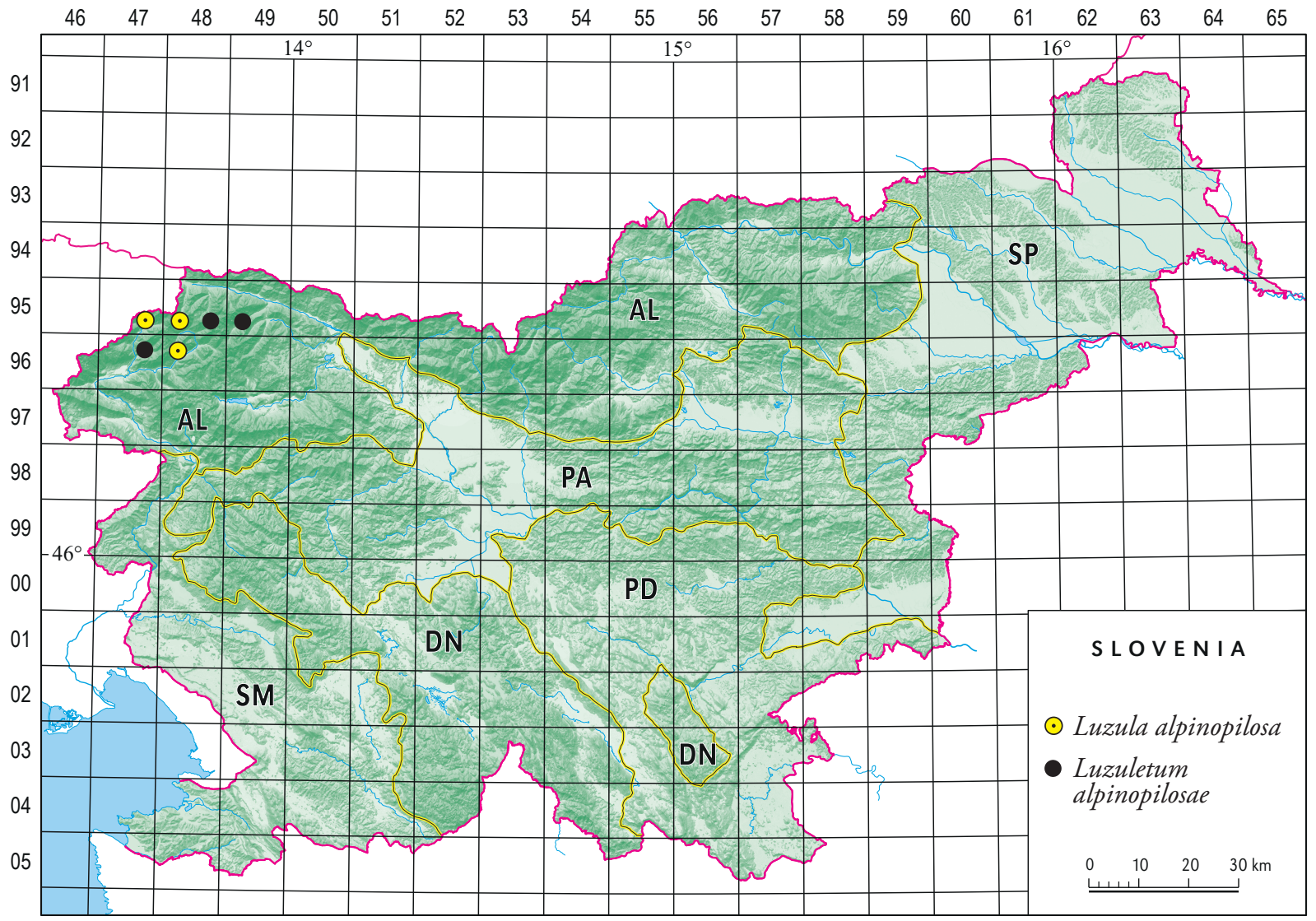

Figure 1: Distribution of Luzula alpinopilosa in Slovenia (according to the data in FloVegSi database, authors B. Anderle, I. Dakskobler, A. Martinčič, A. Podobnik, B. Surina, B. Vreš, T. Wraber) and approximate localities of studied stands.

Slika 1: Razširjenost vrste Luzula alpinopilosa v Sloveniji (po podatkih v bazi FloVegSi, avtorji B. Anderle, I. Dakskobler, A. Martinčič, A. Podobnik, B. Surina, B. Vreš, T. Wraber) in približna nahajališča preučenih sestojev. 
Oxyrietum digynae and Hieracietum intybacei (Poldini \& Martini 1993). The association Luzuletum spadiceae Rübl 1911 in the Alps comprises initial communities of alpine screes, erosion areas, landslide areas, snow beds on silicate bedrock (Englisch 1993: 396-398, Pignatti \& Pignatti 2014: 477). The association Taraxaco carinthiaci-Luzuletum alpino-pilosae (Lasen 1982, Pignatti \& Pignatti 2014: 476-477) is reported for the southern limestone Alps in northern Italy, in terrain depressions with long-lasting snow cover. The parent material is flint limestone. In the Austrian part of the Central Alps, in the Lower (Niedere) Tauern, in the Radstadt (Radstädter) Tauern Heiselmayer (1982) described the subassociation Luzuletum alpinopilosae salicetosum retusae, whose stands are characteristic for silicate areas with an admixture of calcareous rocks and occurring on gentle to steep shady slopes at the elevations ranging between 2100 and $2300 \mathrm{~m}$. Its differential species are Salix retusa, Silene acaulis, with a lower frequency also Sesleria caerulea and Carex sempervirens. Our syntaxonomic classification of the stands with dominant Luzula alpinopilosa from the Julian Alps was based on the comparison with similar alpine woodrush communities in the Alps.

\section{Methods}

Alpine grasslands with dominant Luzula alpinopilosa were studied applying the Braun-Blanquet method (BraunBlanquet 1964). The relevés from Slovenia were entered into the FloVegSi database (Fauna, Flora, Vegetation and Paleovegetation of Slovenia) of the Jovan Hadži Institute of Biology at ZRC SAZU (T. Seliškar et al. 2003) and together with relevés from Friuli Venezia Giulia arranged into Table 1 based on hierarchical classification. We transformed the combined cover-abundance values with numerical values (1-9) according to van der Maarel (1979). Numerical comparisons were performed with the SYN-TAX 2000 program package (Podani 2001). The relevés were compared by means of "(unweighted) average linkage method" - UPGMA, using Wishart's similarity ratio. Communities from Slovenia and Friuli were compared with similar, already described communities in the Alps. We constructed a synthetic table (Table 2). Hierarchical classification was employed in this comparison as well, and the same method was used as in our comparison of individual relevés, but the measure of dissimilarity was also Jaccard's Index.

The nomenclatural source for the names of vascular plants are the Mala flora Slovenia (MFS - Martinčič et al. 2007), Flora alpina (Aeschimann et al. 2004a,b,c) and Poldini et al. (2001) The nomenclature of Flora alpina - Sesleria caerulea was used for the taxon Sesleria caerulea subsp. calcaria (MFS) and Gnaphalium for the genus Omalotheca (MFS). The nomenclature of Vascular flora of Friuli Vene- zia Giulia was used for the taxon Achillea clavennae. Frahm \& Frey (1992) and Martinčič (2003) are the nomenclatural source for the names of mosses, and Wirth (1995) and Suppan et al. (2000) for the names of lichens. The names of syntaxa follow Englisch (1993), Grabherr \& Mucina (1993), Theurillat (2004), Surina \& Dakskobler (2017), Šilc \& Čarni (2012) and Mucina et al. (2016). In the classification of species into phytosociological groups (groups of diagnostic species) we mainly refer to the Flora alpina (Aeschimann et al. 2004a,b). The geographic coordinates of relevés from Slovenia are determined according to the Slovenian geographic coordinate system D 48 (5th zone) on the Bessel ellipsoid and with Gauss-Krüger projection.

All of the relevés discussed in this article were made in the alpine belt of the Julian and Carnic Alps. The geological bedrock in the study area is mainly calcareous, limestone and dolomite limestone, interlayered with more silicate rocks, marlstone, claystone and chert (Buser 2009), in the Carnic Alps Werfen sandstone and limestone. The studied communities occur on different forms of rendzina (rendzina on limestone with chert intercalations), and on Eutric or Dystric Ranker (Vidic et al. 2015). The climate is montane, with mean annual precipitation of 2500 to $3000 \mathrm{~mm}$ (Zupančič 1998) and mean annual air temperature of -2 to $0^{\circ} \mathrm{C}$ (Cegnar 1998). The researched stands are usually covered with snow from November to June. The growing season usually lasts from the middle of June to the end of September (or beginning of October).

\section{Results and discussion}

Through hierarchical classification as demonstrated in Figure 2, the 15 stands of alpine grasslands with dominant Luzula alpinopilosa from the Julian Alps (made by ID Igor Dakskobler and TW Tone Wraber) in Figure 1 and 8 relevés from the Carnic Alps (made by LP Livio Poldini) grouped together. Most of the relevés from the Carnic Alps, except for two, formed a separate cluster, so we marked the relevés from the Julian Alps TWID and the relevés from the Carnic Alps LP (Table 2, synthetic table).

The following syntaxa were also arranged in the synthetic table:

- BB Luzuletum spadiceae, Central Alps, Braun-Blanquet \& Jenny (1926, Table 5, relevés 12-14)

- CL Taraxaco carinthiaci-Luzuletum alpinopilosae, Alps near Feltre, Lasen 1982

- PH Luzuletum alpinopilosae salicetosum retusae Heiselmayer 1982, Radstädter Tauern (Central Alps in Austria), Heiselmayer (1982, Table 8, Columns 3-5).

The synthetic table does not comprise snow bed communities from the High Tauern, which Friedel (1956) classified as the association Juncetum jacquinii whereas 


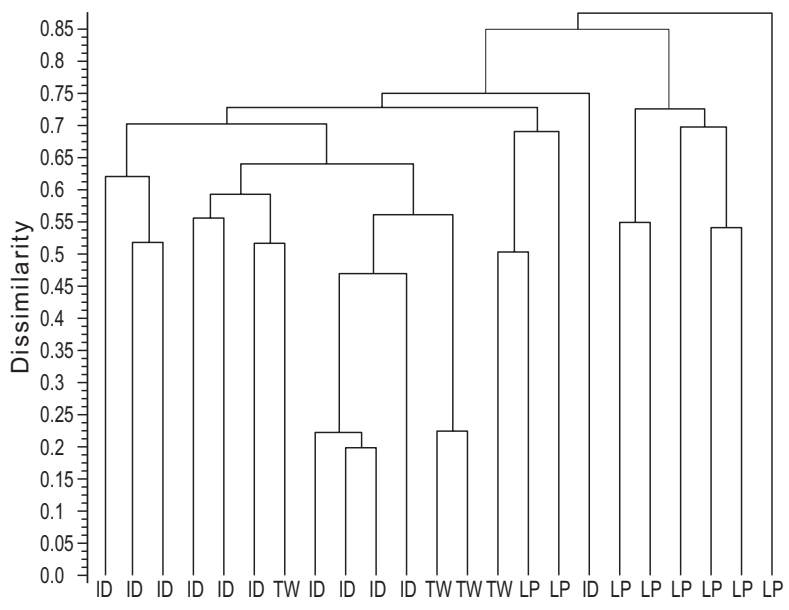

Figure 2: Dendrogram of alpine grassland communities with dominant Luzula alpinopilosa from the Julian Alps (ID, TW) and Carnic Alps (LP), UPGMA, 1-similarity ratio.

Slika 2: Dendrogram alpinskih združb s prevladujočo vrsto Luzula alpinopilosa v Julijskih Alpah (ID, TW) in Karnijskih Alpah (LD), UPGMA, Wishartov količnik različnosti (1-similarity ratio).

Englisch (1993) discussed it in the framework of the association Luzuletum spadiceae. Friedel's relevé characterises a syntaxon with dominant Salix herbacea and Juncus jacquinii, and indicates the presence of Luzula alpinopilosa, so it is clearly different from our relevés.

Hierarchical classification was performed in two ways, by taking into account the constancy of species (Figure 3) and by taking into account only presence or absence of species (Figure 4).

The results are not similar, but indicate that the communities with dominant Luzula alpinopilosa on mixed, calcareous-silicate bedrock are floristically distinctly different

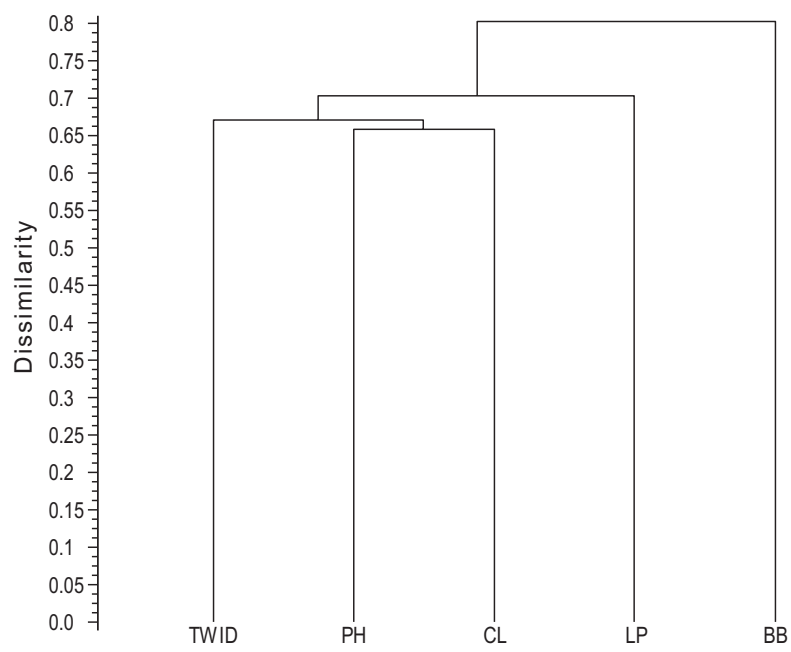

Figure 3: Dendrogram of five communities with dominant Luzula alpinopilosa in the Alps, UPGMA, 1-similarity ratio.

Slika 3: Dendrogram petih združb s prevladujočo vrsto Luzula alpinopilosa v Alpah, UPGMA, Wishartov količnik različnosti

(1-similarity ratio).
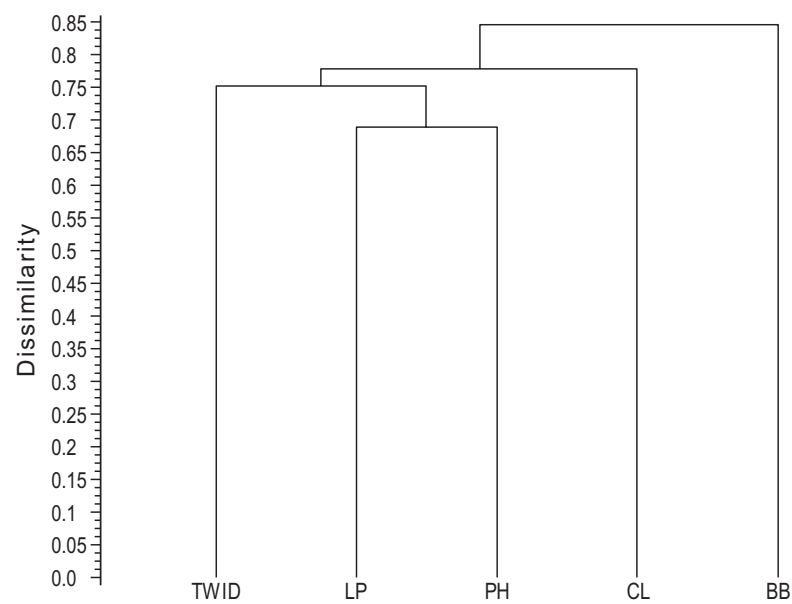

Figure 4: Dendrogram of five communities with dominant Luzula alpinopilosa in the Alps, UPGMA, 1-Jaccard.

Slika 4: Dendrogram petih združb s prevladujočo vrsto Luzula alpinopilosa v Alpah, Jaccardov količnik različnosti (1-Jaccard).

from communities with this species on silicate bedrock and cannot reliably be classified into the same association. The relevés from the Julian Alps cannot be classified into the association Taraxaco-Luzuletum alpinopilosae either, because floristic similarity between them (according to Sørensen 1948 ) is only about $35 \%$, even though the taxon Taraxacum carinthiacum also belongs into the section Taraxacum sect. Alpina that occurs in several relevés also in the stands from the Julian Alps. In terms of Sørensen's similarity index (1948) the floristic similarity of the stands from the Julian Alps with the stands of the subassociation Luzuletum alpinopilosae salicetosum retusae is only about $40 \%$, although both compared communities comprise several shared diagnostic species (Salix retusa, S. reticulata, Juncus jacquinii, Geum montanum, Potentilla aurea, Homogyne alpina, Silene acaulis, Galium anisophyllum, Doronicum glaciale). The reason for low floristic similarity between these two syntaxa is that their stands occur in very different phytogeographical areas (Southeast Limestone Alps and Central Alps, respectively) and also in different ecological conditions. Considering only the presence and absence of species the relevés from the Carnic Alps are the most similar to the relevés from the Lower Tauern (Niedere Tauern) in Austria; when taking into account the species constancy, the similarity is smaller and the relevés group separately.

As Salix retusa is very rare in the relevés of the stands from the Carnic Alps, classification into the subassociation Luzletum alpinopilosae salicetosum retusae is not optimal, because of the absent Taraxacum carinthiacum (Taraxacum sect. Alpina), nor can it be classified into the association Taraxaco carinthiaci-Luzuletum alpinopilosae. Because two of the relevès from the Carnic Alps are floristically closer to some of the relevès from the Julian Alps 
(see Figure 2), other relevès from the Carnic Alps could also still be treated in the framework of the community from the Julian Alps. Based on the comparisons made, we classify the studied stands from the Julian and Carnic Alps into the new association Junco jacquinii-Luzuletum alpinopilosae. Its diagnostic species are Luzula alpinopilosa, Juncus jacquinii, Geum montanum, Rhodiola rosea, Phleum rhaeticum and Trifolium pallescens. The geographical differential species are Doronicum glaciale, Homogyne discolor and Astrantia bavarica. Diagnostic species characterise nutrient-rich, moist and slightly acidic alpine grasslands on mixed geological bedrock in the (South)Eastern Alps. The nomenclatural type, holotypus, of the new association is relevé 9 in Table 1 . The classification of the new association into higher syntaxonomic units is very problematic. According to the groups of diagnostic species (Table 3, Columns 1 and 2) the proportion of the species of the class Elyno-Seslerietea (including syntaxa Caricion ferrugineae, Oxytropido-Elynion, Caricion austroalpinae, Caricion firmae, Seslerion coeruleae) totals $28.44 \%$ (for the subunits from the Julian Alps), and $13.27 \%$ (for the subunit from the Carnic Alps). The proportion of the diagnostic species of the class Juncetea trifidi (including syntaxa Nardion strictae, Loiseleurio-Vaccinietea, VaccinioPiceetea and Oxycocco-Sphagnetea) is $24.74 \%$ (for the subunits from the Julian Alps) and $43.33 \%$ (for the subunit from the Carnic Alps). The proportion of diagnostic species of classes Salicetea herbaceae and Thlaspietea rotundifolii (including syntaxa Androsacetalia alpinae and Arabidetalia caeruleae) is $18.63 \%$ (for the subunits from the Julian Alps) and 27.33\% (for the subunit from the Carnic Alps). Beside these groups, at least in the subunits from the Julian Alps, there is a relatively high proportion of diagnostic species of the class Mulgedio-Aconitetea (10.4\%) and of the order Poo alpinae-Trisetetalia (9.38\%). According to this analysis classification into the classes Salicetea herbaceae or Thlaspietea rotundifolii is not possible. If we had to decide between classes Elyno-Seslerietea and Juncetea trifidi, the last would have priority, because Juncus jacquinii and Geum montanum, two frequent diagnostic species of the new association, both belong into this class. There are two syntaxa of this class for the communities in the Southeastern Alps: Caricion curvulae Br.-Bl. 1925 (order Caricetalia curvulae), which includes alpine sedge swards on siliceous substrates of the Alps, and the Eastern and Southern Carpathians and order Festucetalia spadiceae Barbero 1970, which includes acidophilic subalpine and alpine species-rich grasslands of the Alps, the Carpathians and the Northern Apennines, with two alliances, Nardion strictae and Festucion variae (Mucina et al. 2016: 79). Our community does not fit entirely into any of these tree alliances, so we suggest a description of a new alliance
Doronico glacialis-Juncion jacquinii all. nov. prov. (order Festucetalia spadiceae) with diagnostic species Luzula alpinopilosa, Juncus jacquinii, Leontodon helveticus, Geum montanum, Carex ferruginea, Festuca nigrescens, Salix retusa, Doronicum glaciale and Homogyne discolor. In the new alliance should be included species rich alpine grassland communities on mixed carbonate-silicate parent material and on moist (shady) sites with long snow cover in the (South)Eastern Alps (communities with relatively equivalent proportion of diagnostic species of the classes Juncetea trifidi, Elyno-Seslerietea and Salicetea herbaceae, including Thlaspietea rotundifolii, but with dominant species of the classes Juncetea trifidi or Salicetea herbaceae).

We distinguish three subassociations of the new association:

- galietosum anisophyllae subass. nova hoc loco with differential species Galium anisophyllum, Potentilla crantzii, Pedicularis verticillata and Koeleria eryostachia; also differential are other diagnostic species of the syntaxa Caricion austroalpinae, Seslerion coeruleae, Elyno-Seslerietea and also Arabidetalia caeruleae, which indicate predominantly calcareous bedrock and contact with alpine grasslands from the class Elyno-Seslerietea. The nomenclatural type, holotypus, of the new subassociation is relevé 5 in Table 1.

- potentilletosum aureae subass. nova hoc loco, with differential species Potentilla aurea, Soldanella pusilla and Rumex arifolius. Its nomenclatural type, holotypus, is the same as the nomenclatural type of the new association, relevé 9 in Table 1, and characterises the typical form of a moist alpine grassland on mixed calcareous-silicate bedrock.

- leucanthemopsietosum alpinae subass. nova hoc loco, with differential species Leucanthemopsis alpina, Hieracium alpinum and Arenaria biflora. Its nomenclatural type, holotypus, is relevé 18 in Table 1 and comprises relevés from the Carnic Alps that are floristically very different and could be classified also into the association Luzuletum alpinopilosae s. lat.

\section{Conclusions}

Luzula alpinopilosa is relatively rare in Slovenia and occurs only in the alpine belt in the Julian Alps, on areas with persistent snow cover where the soil is consequently moist and, due to silicate intercalations, also acidic. It is characteristic for snow bed communities (Salicetum herbaceae s. lat.) as well as for alpine grasslands in gullies and shady promontories classified into the new association Junco jacquinii-Luzuletum alpinopilosae. Its classification into higher syntaxonomic units is very problematic, so we suggest a description of a new alliance Doronico 
glacialis-Juncion jacquinii all. nov. prov. (order Festucetalia spadiceae and class Juncetea trifidi). Larger areas of these grasslands are on ledges under the ridge of the rock wall of Loška Stena (especially in its northeastern part, from Mt. Bedinji Vrh to Mt. Plešivec) and under Mt. Mangart, smaller areas also under several other summits. Their past development was largely the result of grazing of small ruminants, in particular sheep, and this impact is still evident today (regular grazing of sheep on Jarečica under Mt. Mangart, occasional smaller flocks on the ridge of Loška Stena from Mt. Plešivec to Mt. Bedinji Vrh). Shady ledges under the rock wall of Loška Stena are frequently visited also by chamois (Kozje Police under Bedinji Vrh). This high-mountain region is very difficult to access, so there are no other direct human impacts here. Syndynamically, these stands can be connected with the rusty sedge community (Caricetum ferruginae s. lat.), in places even with tall herb communities (Aconito-Peucedanetum ostruthii). They are the sites of several rare or endangered Red List species (Anonymous 2002): Carex curvula. Coeloglossum viride, Helictotrichon versicolor (= Helictochloa versicolor), Juncus trifidus, Luzula alpinopilosa and Trifolium thalii. Stands with the dominant Luzula alpinopilosa in the Carnic Alps in northeastern Italy are different in terms of ecology and species composition. Because some of them are classified into the subassociation Junco jacquini-Luzuletum alpinopilosae potentilletosum aureae, it is, for now, possible also for other relevés from this area to be classified into the same association as the new subassociation-leucanthemopsietosum alpinae.

\section{Povzetek}

\section{Alpinska travišča s prevladujočo vrsto Luzula alpino- pilosa v Julijskih in Karnijskih Alpah}

Fitocenološko smo preučili alpinska travišča v žlebovih in na osojnih pomolih na nadmorski višini med $2100 \mathrm{~m}$ in $2500 \mathrm{~m}$ v Julijskih Alpah (Mangart, Jarečica, Plešivec, Bedinji vrh, Zadnji Pelc, Skutnik/Sončni Jelenk) in Karnijskih Alpah, v katerih prevladuje vrsta Luzula alpinopilosa in jih na podlagi primerjav s podobnimi združbami drugod v Alpah uvrstili v novo asociacijo Junco jacquinii-Luzuletum alpinopilosae. Njene diagnostične vrste so Luzula alpinopilosa, Juncus jacquinii, Geum montanum, Rhodiola rosea, Phleum rhaeticum in Trifolium pallescens, geografske razlikovalnice pa vrste Doronicum glaciale, $\mathrm{Ho}$ mogyne discolor in Astrantia bavarica. Označujejo s hranili bogata, vlažna in nekoliko zakisana alpinska travišča na mešani geološki podlagi. Uvrstitev nove asociacije v višje sintaksonomske enote je nekoliko problematična, saj so $\mathrm{v}$ njej precej enakovredno zastopane diagnostične vrste treh oz. štirih razredov (Juncetea trifidi, Elyno-Seslerietea in Thlaspietea rotundifolii, vključno z razredom Salicetea herbaceae). Predlagamo opis nove zveze Doronico glacialis-Juncion jacquinii znotraj reda Festucetalia spadiceae in razreda Juncetea trifidi. Razlikujemo tri subasociacije: galietosum anisophyllae z razlikovalnicami Galium anisophyllum, Potentilla crantzii, Pedicularis verticillata in Koeleria eryostachia, razlikovalne pa so tudi druge diagnostične vrste sintaksonov Caricion austroalpinae, Seslerion coeruleae, Elyno-Seslerietea in tudi Arabidetalia caeruleae, ki kažejo na prevladujočo karbonatno podlago in na stik $s$ alpinskimi travišči iz razreda Elyno-Seslerietea, -potentilletosum aureae, z razlikovalnicami Potentilla aurea, Soldanella pusilla in Rumex arifolius, ki označuje tipično obliko vlažnega alpinskega travišča na mešani karbonatno-silikatni podlagi in -leucanthemopsietosum alpinae z razlikovalnicami Leucanthemopsis alpina, Hieracium alpinum in Arenaria biflora, v kateri so združeni le nekateri popisi iz Karnijskih Alp, ki so floristično precej drugačni in bi jih bilo mogoče uvrstiti tudi v asociacijo Luzuletum alpinopilosae s. lat. $\mathrm{Na}$ razvoj teh floristično za Julijske Alpe precej posebnih travišč je $\mathrm{v}$ preteklosti precej vpliva paša drobnice, predvsem ovac in ta vpliv se kaže še zdaj (pogosta paša ovac na Jarečici pod Mangartom, občasni manjši tropi na grebenu Loške stene od Plešivca do Bedinjega vrha in naprej Moreža). Na osojnih policah pod Loško steno (na primer Kozje police pod Bedinjim vrhom) se pogosto zadržujejo tudi gamsi. Drugih neposrednih človekovih posegov na ta težko dostopna pobočja ni. Sindinamsko so ti sestoji lahko povezani z združbo rjastega šaša (Caricetum ferruginae s. lat.), ponekod celo z združbami visokih steblik (Aconito-Peucedanetum ostruthii). So rastišča več redkih ali ogroženih vrst iz rdečega seznama (Anonymous 2002): Carex curvula, Coeloglossum viride, Helictotrichon versicolor, Juncus trifidus, Luzula alpinopilosa in Trifolium thalii.

\section{Acknowledgements}

We would like to thank the heirs of the late Prof. Dr. Tone Wraber for giving his manuscripts and professional literature to the safekeeping of the Botanical Garden of the University of Ljubljana, and to its director, Dr. Jože Bavcon, who allowed us to examine professor's legacy. We owe special thanks to Brane Anderle, Prof. Dr. Andrej Martinčič, mag. Andrej Podobnik, mag. Andrej Seliškar, Prof. Dr. Boštjan Surina and Dr. Branko Vreš, co-authors of Figure 1 and to Prof. Dr. Božo Frajman for his help with some literature sources. Anonymous reviewer helped us with valuable improvements and corrections. We also acknowledge the financial support from the Slovenian Research Agency (research core funding No. P1-0236). English translation by Andreja Šalamon Verbič. 


\section{References}

Aeschimann, D., Lauber, K., Moser, D. M. \& Theurillat, J.-P. 2004a: Flora alpina. Bd. 1: Lycopodiaceae-Apiaceae. Haupt Verlag, Bern, Stuttgart, Wien, $1159 \mathrm{pp}$.

Aeschimann, D., Lauber, K., Moser, D. M. \& Theurillat, J.-P. 2004b: Flora alpina. Bd. 2: Gentianaceae-Orchidaceae. Haupt Verlag, Bern, Stuttgart, Wien, 1188 pp.

Aeschimann, D., Lauber, K., Moser, D. M. \& Theurillat, J.-P. 2004c: Flora alpina. Bd. 3: Register. Haupt Verlag, Bern, Stuttgart, Wien, 322 pp.

Anonymous 2002: Pravilnik o uvrstitvi ogroženih rastlinskih in živalskih vrst v rdeči seznam. Uradni list RS 82/2002.

Braun-Blanquet, J. \& Jenny, J. 1926: Vegetationsentwicklung und Bodenbildung in der alpinen Stufe der Zentralalpen. Denkschr. Schweiz. Naturforsch. Ges. Zürich 63: 183-349.

Braun-Blanquet, J. 1964: Pflanzensoziologie. Grundzüge der Vegetationskunde. 3. Auflage. Springer, Wien - New York, 865 pp.

Buser, S. 2009: Geološka karta Slovenije 1: 250.000. Geological map of Slovenia 1: 250,000. Geološki zavod Slovenije, Ljubljana.

Cegnar, T. 1998: Temperatura zraka. In: Fridl, J., Kladnik, D., Orožen Adamič, M. \& Perko, D. (eds.): Geografski atlas Slovenije. Država v prostoru in času. Državna založba Slovenije, Ljubljana, pp. 100-101.

Englisch, T. 1993: Salicetea herbaceae. In: Mucina, L., Grabherr, G. \& Ellmauer, T. (eds.): Die Pflanzengesellschaften Österreichs. Teil II. Gustav Fischer Verlag, Jena. pp. 389-399.

Frahm, J. P. \& Frey, W. 1992: Moosflora. 3. Aufl. UTB, Ulmer, Verlag, Stuttgart, 528 pp.

Friedel, H. 1956: Alpine Vegetation des obersten Mölltales (Hohe Tauern). Wissenschaftliche Alpenvereinshefte, Heft 16: 1-153, Universitätsverlag Wagner, Innsbruck.

Grabherr, G. \& Mucina, L. (eds.) 1993: Die Pflanzengesellschaften Österreichs. Teil II: Natürliche waldfreie Vegetation. Gustav Fischer Verlag, Jena - Stuttgart - New York. 523 pp.

Heiselmayer, P. 1982: Die Pflanzengesellschaften des Tappenkars (Radstädter Tauern). Stapfia 10: 161-202.

Lasen, C. 1982: Vegetazione nivali a Luzula alpino-pilosa nelle Alpi Feltrine. Studi Trentini di Scienza Naturali 59: 31-40.

Maarel van der, E. 1979: Transformation of cover-abundance values in phytosociology and its effects on community similarity. Vegetatio 39 (2): $97-114$

Martinčič, A. 2003: Seznam listnatih mahov (Bryopsida) Slovenije. Hacquetia 2 (1): 91-166.

Martinčič, A., Wraber, T. \& Dakskobler, I. 2019: Snowbed communities with dominant Salix herbaceae in the Julian Alps. Hacquetia 18 (1): 47-73.

Martinčič, A., Wraber, T., Jogan, N., Podobnik, A., Turk, B., Vreš, B., Ravnik, V., Frajman, B., Strgulc Krajšek, S., Trčak, B., Bačič, T., Fischer, M. A., Eler, K. \& Surina, B. 2007: Mala flora Slovenije. Ključ za določanje praprotnic in semenk. Četrta, dopolnjena in spremenjena izdaja. Tehniška založba Slovenije, Ljubljana, 967 pp.

Mucina, L., Bültmann, H., Dierßen, K., Theurillat, J.-P., Raus, T., Čarni, A., Šumberová, K., Willner, W., Dengler, J., Gavilán García,
R., Chytrý, M., Hájek, M., Di Pietro, R., Iakushenko, D., Pallas, J., Daniëls, F. J. A., Bergmeier, E., Santos Guerra, A., Ermakov, N., Valachovič, M., Schaminée, J. H. J., Lysenko, T., Didukh, Y. P., Pignatti, S., Rodwell, J. S., Capelo, J., Weber, H. E., Solomeshch, A., Dimopoulos, P., Aguiar, C., Hennekens, S. M. \& Tichý, L. 2016 Vegetation of Europe: hierarchical floristic classification system of vascular plant, bryophyte, lichen, and algal communities. Applied Vegetation Science 19, Suplement 1: 3-264.

Pignatti, E. \& Pignatti, S. 2014: Plant Life of the Dolomites. Vegetation Structure and Ecology. Publication of the Museum of Nature South Tyrol Nr. 8, Naturmuseum Südtirol, Bozen, Springer Verlag, Heidelberg, 769 pp.

Podani, J. 2001: SYN-TAX 2000. Computer Programs for Data Analysis in Ecology and Systematics. User's Manual, Budapest, 53 pp.

Poldini, L. \& Martini, F. 1993: La vegetazione delle vallette nivali su calcare, dei conoidi e delle alluvioni nel Friuli (NE Italia). Studia Geobotanica 13: 141-214.

Poldini, L. (with collaboration of G. Oriolo \& M. Vidali), 2002: Nuovo Atlante corologico delle piante vascolari nel Friuli Venezia Giulia. Regione Autonoma Friuli Venezia Giulia, Azienda Parchi e Foreste Regionali \& Università degli Studi di Trieste, Dipartimento di Biologia, Udine, 529 pp.

Poldini, L., Oriolo, G. \& Vidali, M. 2001: Vascular flora of Friuli Venezia Giulia. An annotated catalogue and synonymic index. Studia Geobotanica 21: 3-227.

Poldini, L. \& Vidali, M. 1995: Prospetto sistematico della vegetazione nel Friuli-Venezia Giulia. Atti dei Convegni Lincei 115. XI Giornata dell' Ambiente Convegno sul tema: La Vegetazione Italiana (Roma, 5. giugno 1993), Accademia nazionale dei Lincei, Roma. pp. 155-174.

Seliškar, T., Vreš, B. \& Seliškar, A. 2003: FloVegSi 2.0. Računalniški program za urejanje in analizo bioloških podatkov. Biološki inštitut ZRC SAZU, Ljubljana.

Sørensen, Th. 1948: A method of establishing groups of equal amplitude in plant sociology based on similarity of species content. Det Kongelige Danske Videnskaberns Selskab, Biologiske Skrifter 5 (4): 1-34.

Suppan, U., Prügger, J. \& Mayrhofer, H. 2000: Catalogue of the lichenized and lichenicolous fungi of Slovenia. Bibliotheca Lichenologica 76: 1-215.

Šilc, U. \& Čarni, A. 2012: Conspectus of vegetation syntaxa in Slovenia. Hacquetia 11 (1): 113-164.

Theurillat, J.-P. 2004: Pflanzensoziologisches System. In: Aeschimann, D., Lauber, K., Moser, D. M. \& Theurillat, J.-P.: Flora alpina, 3. Haupt Verlag, Bern, Stuttgart, Wien, pp. 301-313.

Vidic, N. J., Prus, T., Grčman, H., Zupan, M., Lisec, A., Kralj, T., Vrščaj, B., Rupreht, J., Šporar, M., Suhadolc, M., Mihelič, R. \& Lobnik, F. 2015: Tla Slovenije s pedološko karto v merilu 1:250 000. Soils of Slovenia with soil map 1: 250 000. European Union \& University of Ljubljana, Luxemburg, Ljubljana, 152 pp. + maps.

Wirth, V. 1995: Flechtenflora. 2. Auf. Verlag Eugen Ulmer, Stuttgart, $661 \mathrm{pp}$.

Zupančič, B. 1998: Padavine. In: Fridl, J., Kladnik, D., Orožen Adamič, M. \& Perko, D. (eds.): Geografski atlas Slovenije. Država v prostoru in času. Državna založba Slovenije, Ljubljana, pp. 98-99. 
Table 1 (Tabela 1): Junco jacquinii-Luzuletum alpinopilosae ass. nov.

\begin{tabular}{|c|c|c|c|c|c|c|c|c|}
\hline Number of relevé (Zaporedna številka popisa) & & 1 & 2 & 3 & 4 & 5 & 6 & 7 \\
\hline Database number of relevé (Delovna številka popisa) & & 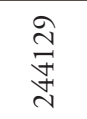 & $\begin{array}{l}\infty \\
\stackrel{\infty}{0} \\
\stackrel{\sim}{f} \\
\stackrel{\sim}{\sim}\end{array}$ & \begin{tabular}{l} 
సે \\
\multirow{+}{*}{} \\
$\curvearrowleft$
\end{tabular} & 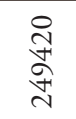 & $\begin{array}{l}\stackrel{+}{\varpi} \\
\stackrel{2}{n} \\
\stackrel{\sim}{v}\end{array}$ & 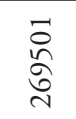 & 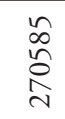 \\
\hline Author of the relevé (Avtor popisa) & & ID & ID & ID & ID & ID & ID & TW \\
\hline Elevation in $\mathrm{m}$ (Nadmorska višina $\mathrm{v} \mathrm{m})$ & & 2165 & 2295 & 2172 & 2245 & 2195 & 2160 & 2500 \\
\hline Aspect (Lega) & & NW & NW & $\mathrm{N}$ & NW & NW & $\mathrm{N}$ & W \\
\hline Slope in degrees (Nagib v stopinjah) & & 30 & 35 & 15 & 25 & 15 & 35 & 25 \\
\hline Parent material (Matična podlaga) & & A & A & A & ALR & $\mathrm{AL}$ & $\mathrm{AL}$ & A \\
\hline Soil (Tla) & & $\operatorname{Re}$ & $\operatorname{Re}$ & $\operatorname{Re}$ & Dy & Dy & $\operatorname{Re}$ & $\operatorname{Re}$ \\
\hline Stoniness in \% (Kamnitost $\mathrm{v} \%$ ) & & 5 & 5 & 5 & . & . & 1 & . \\
\hline Cover of herb layer in \% (Zastiranje zeliščne plasti $\mathrm{v} \%$ ): & E1 & 90 & 95 & 95 & 100 & 100 & 95 & 100 \\
\hline Cover of moss layer in \% (Zastiranje mahovne plasti v \%) & E0 & . & . & 5 & . & . & . & . \\
\hline Number of species (Število vrst) & & 41 & 34 & 27 & 30 & 31 & 35 & 13 \\
\hline Relevé area (Velikost popisne ploskve) & $\mathrm{m}^{2}$ & 10 & 3 & 4 & 10 & 20 & 20 & 50 \\
\hline Date of relevé (Datum popisa) & & 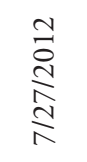 & $\begin{array}{l}\stackrel{N}{*} \\
\stackrel{N}{N} \\
\frac{\infty}{\infty}\end{array}$ & 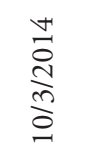 & $\frac{\substack{0 \\
\stackrel{\infty}{\infty}}}{\frac{\infty}{\infty}}$ & $\frac{\underset{N}{N}}{\stackrel{N}{N}}$ & 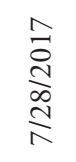 & $\frac{\infty}{\stackrel{\infty}{\infty}}$ \\
\hline Locality (Nahajališče) & & $\begin{array}{c}\frac{y}{\vec{\Xi}} \\
\frac{\vec{y}}{\omega}\end{array}$ & $\begin{array}{l}\frac{u}{v} \\
:= \\
: \bar{v} \\
\frac{\vec{v}}{N}\end{array}$ & 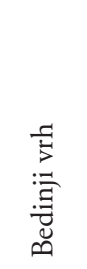 & 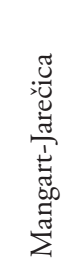 & 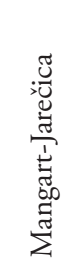 & 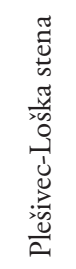 & 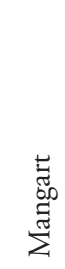 \\
\hline Quadrant (Kvadrant) & & 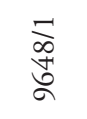 & $\begin{array}{l}\underset{\infty}{\infty} \\
\underset{\sigma}{0} \\
\curvearrowleft\end{array}$ & 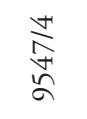 & 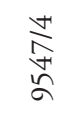 & 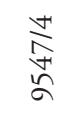 & $\underset{\sigma}{\stackrel{+}{\gtrless}}$ & 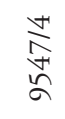 \\
\hline Coordinate GK Y (D-48) & $\mathrm{m}$ & $\begin{array}{l}\stackrel{+}{ } \\
\stackrel{\infty}{\infty} \\
\infty \\
\approx\end{array}$ & $\begin{array}{l}\infty \\
\infty \\
\infty \\
\infty \\
\infty\end{array}$ & 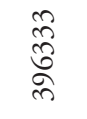 & 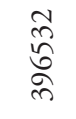 & 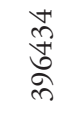 & $\begin{array}{l}\hat{\infty} \\
\stackrel{N}{N} \\
\hat{\curvearrowright}\end{array}$ & 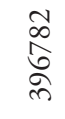 \\
\hline Coordinate GK X (D-48) & $\mathrm{m}$ & $\begin{array}{l}\stackrel{m}{f} \\
\stackrel{\infty}{\infty} \\
\stackrel{m}{n}\end{array}$ & 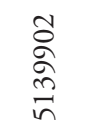 & $\begin{array}{l}\text { Nิ } \\
\hat{\text { o }} \\
\stackrel{+}{n} \\
\text { n }\end{array}$ & $\begin{array}{l}\overrightarrow{\hat{S}} \\
\underset{+}{ \pm} \\
\stackrel{+}{n}\end{array}$ & \begin{tabular}{l} 
త్ర \\
\multirow{+}{*}{} \\
\multirow{\forall}{*}{}
\end{tabular} & $\underset{\sim}{\stackrel{\leftrightarrow}{F}}$ & $\begin{array}{l}8 \\
\stackrel{2}{2} \\
\underset{\forall}{ \pm} \\
\sqrt{n}\end{array}$ \\
\hline
\end{tabular}

\begin{tabular}{ll}
\hline & Diagnostic species of \\
SH & Luzula alpinopilosa \\
JT & Juncus jacquinii \\
JT & Geum montanum \\
TR & Rhodiola rosea \\
AC & Trifolium pallescens \\
PaT & Phleum rhaeticum \\
AC & Doronicum glaciale \\
ES & Homogyne discolor \\
ES & Astrantia bavarica \\
& Differential species of \\
SV & Galium anisophyllum \\
ES & Pedicularis verticillata \\
SV & Potentilla crantzii \\
CA & Koeleria eriostachya
\end{tabular}




\begin{tabular}{|c|c|c|c|c|c|c|c|c|c|c|c|c|c|c|c|}
\hline 8 & 9 & 10 & 11 & 12 & 13 & 14 & 15 & 16 & 17 & 18 & 19 & 20 & 21 & 22 & 23 \\
\hline \begin{tabular}{l}
$\vec{\sigma}$ \\
\multirow{\sigma}{\sigma}{} \\
$\stackrel{d}{ }$
\end{tabular} & 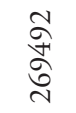 & 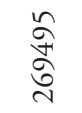 & 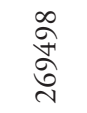 & 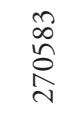 & 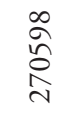 & $\begin{array}{l}\overrightarrow{0} \\
\text { ᄋ } \\
\stackrel{0}{\circ}\end{array}$ & 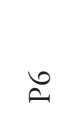 & $\hat{A}$ & \begin{tabular}{l}
$\hat{o}$ \\
\multirow{2}{\hat{~}}{} \\
\end{tabular} & $\bar{a}$ & $\stackrel{+}{a}$ & $\Xi$ & $\stackrel{n}{\sim}$ & $\stackrel{\infty}{1}$ & $\curvearrowleft$ \\
\hline ID & ID & ID & ID & TW & TW & TW & LP & LP & ID & LP & LP & LP & LP & LP & LP \\
\hline 2185 & 2185 & 2180 & 2140 & 2125 & 2125 & 2050 & 2400 & 2420 & 2040 & 2190 & 2030 & 2010 & 2080 & 2060 & 2400 \\
\hline NNE & $\mathrm{N}$ & W & NNE & W & W & NW & $\mathrm{N}$ & $S$ & $\mathrm{NE}$ & $\mathrm{N}$ & $S$ & SW & S & SSW & $\mathrm{N}$ \\
\hline 35 & 25 & 30 & 40 & 15 & 15 & 15 & 10 & 30 & 40 & 45 & 40 & 35 & 35 & 30 & 5 \\
\hline $\mathrm{AL}$ & $\mathrm{AL}$ & AG & $\mathrm{AL}$ & ALR & ALR & ALR & A & A & $\mathrm{AL}$ & WS & WS & WS & WS & WS & A \\
\hline $\operatorname{Re}$ & $\operatorname{Re}$ & $\operatorname{Re}$ & $\operatorname{Re}$ & Dy & Dy & Dy & $\operatorname{Re}$ & $\operatorname{Re}$ & $\operatorname{Re}$ & Dy & Dy & Dy & Dy & Dy & $\operatorname{Re}$ \\
\hline . & . & . & . & . & . & . & . & . & . & . & . & . & . & . & . \\
\hline 100 & 100 & 100 & 95 & 100 & 100 & 100 & 100 & 100 & 100 & 25 & 30 & 50 & 40 & 40 & 40 \\
\hline . & . & . & . & . & . & . & 80 & . & . & . & . & . & . & . & . \\
\hline 12 & 19 & 18 & 32 & 13 & 15 & 13 & 15 & 22 & 20 & 21 & 16 & 23 & 29 & 17 & 17 \\
\hline 4 & 4 & 5 & 20 & 10 & 6 & 4 & 15 & 15 & 20 & 120 & 50 & 45 & 150 & 15 & 15 \\
\hline 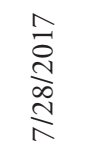 & 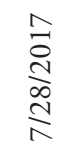 & 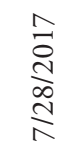 & 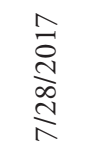 & $\begin{array}{l}\stackrel{\infty}{\infty} \\
\stackrel{\infty}{\equiv} \\
\frac{\infty}{\infty}\end{array}$ & $\frac{\stackrel{\infty}{\infty}}{\stackrel{\infty}{\curvearrowright}}$ & $\begin{array}{l}\infty \\
\stackrel{\infty}{\curvearrowright} \\
\frac{\infty}{\infty}\end{array}$ & $\frac{\stackrel{尺}{\curvearrowright}}{\stackrel{\curvearrowright}{\infty}}$ & $\begin{array}{l}\hat{N} \\
\stackrel{N}{=} \\
\stackrel{\infty}{N} \\
\end{array}$ & 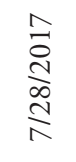 & \begin{tabular}{l}
$\infty$ \\
\multirow{2}{1}{} \\
$\hat{\swarrow}$ \\
$\stackrel{2}{=}$
\end{tabular} & \begin{tabular}{l}
$\infty$ \\
\multirow{2}{1}{} \\
$\hat{\mho}$ \\
$\curvearrowright$
\end{tabular} & 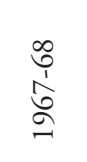 & 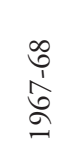 & 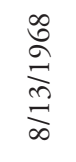 & $\frac{\stackrel{尺}{\curvearrowright}}{\stackrel{\curvearrowright}{\infty}}$ \\
\hline 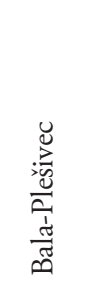 & 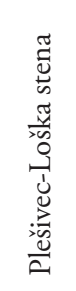 & 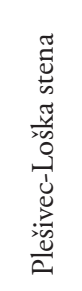 & 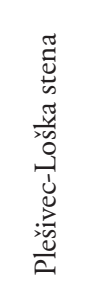 & 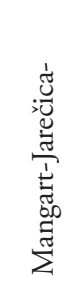 & 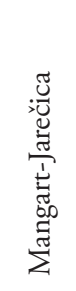 & 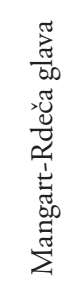 & 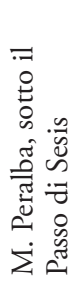 & 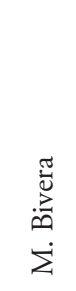 & 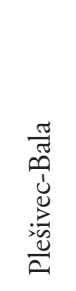 & 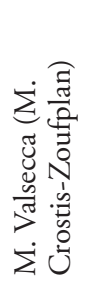 & 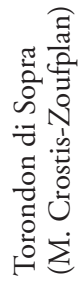 & 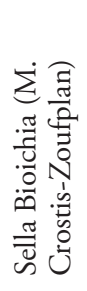 & 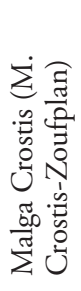 & $\begin{array}{l}\stackrel{n}{0} \\
\stackrel{0}{0} \\
\stackrel{0}{U} \\
\dot{\Sigma}\end{array}$ & 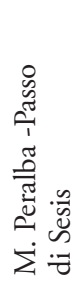 \\
\hline 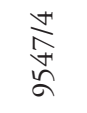 & 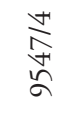 & 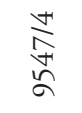 & 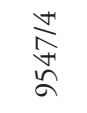 & 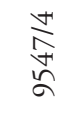 & 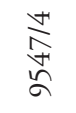 & \begin{tabular}{l}
$\frac{+}{\hbar}$ \\
\multirow{\hbar}{\hbar}{}
\end{tabular} & 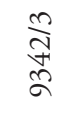 & 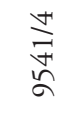 & $\begin{array}{l}\frac{n}{\infty} \\
\stackrel{\infty}{+} \\
\curvearrowleft \\
\curvearrowleft\end{array}$ & $\underset{\sigma}{\stackrel{\varpi}{\rightleftarrows}}$ & 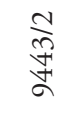 & 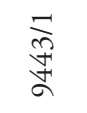 & 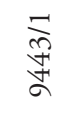 & 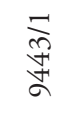 & 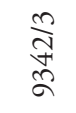 \\
\hline 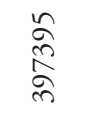 & $\begin{array}{l}\overrightarrow{\hat{n}} \\
\stackrel{\approx}{\hat{n}}\end{array}$ & $\begin{array}{l}\stackrel{+}{N} \\
\stackrel{n}{\hat{n}}\end{array}$ & $\begin{array}{l}\hat{n} \\
\stackrel{\text { }}{\hat{n}}\end{array}$ & $\begin{array}{l}8 \\
\text { గ్ర } \\
\text { ๙ે }\end{array}$ & 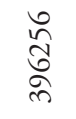 & $\begin{array}{l}\hat{\hat{\sigma}} \\
\hat{\kappa} \\
\hat{n}\end{array}$ & $\cdot$ & . & $\begin{array}{l}\infty \\
\stackrel{\infty}{n} \\
\hat{n} \\
\text { n }\end{array}$ & . & . & $\cdot$ & . & $\cdot$ & . \\
\hline $\begin{array}{l}\stackrel{n}{N} \\
\underset{\sim}{*} \\
i n\end{array}$ & 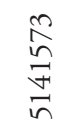 & $\begin{array}{l}\sqrt{6} \\
\stackrel{\sim}{7} \\
\underset{\sim}{n}\end{array}$ & $\begin{array}{l}\stackrel{ }{\vec{n}} \\
\underset{n}{\sharp} \\
\underset{n}{n}\end{array}$ & $\begin{array}{l}\stackrel{\sim}{\sim} \\
\stackrel{n}{f} \\
\stackrel{\sim}{n}\end{array}$ & 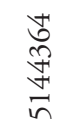 & 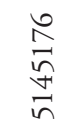 & . & . & $\begin{array}{l}\stackrel{n}{\hat{n}} \\
\stackrel{2}{\varpi} \\
\underset{n}{n}\end{array}$ & . & . & . & . & . & . \\
\hline
\end{tabular}


JT Potentilla aurea

E1

MuA Rumex arifolius

E1

SH Soldanella pusilla

E1

JT Leucanthemopsis alpina (= Tanacetum alpinum) E1

JT Hieracium alpinum E1

ES Arenaria biflora E1

NS Nardion strictae

Festuca nigrescens

Coeloglossum viride

Gentiana punctata

E1

Nardus stricta

E1

Agrostis capillaris

E1

Campanula barbata

E1

Alchemilla flabellata

E1

E1

JT Juncetea trifidi

Leontodon helveticus

Anthoxanthum nipponicum

Campanula scheuchzeri

Helictotrichon versicolor (Helictochloa versicolor)

Agrostis rupestris

Solidago virgaurea subsp. minuta

Juncus trifidus

Luzula spicata

Euphrasia minima

E1

E1

E1

E1

E1

E1

E1

E1

Carex curvula

E1

Oreochloa disticha

E1

Veronica fruticans

E1

Pulsatilla alpina subsp. austriaca

E1

Veronica bellidioides

E1

Festuca cfr. pseudodura

E1

Botrychium lunaria

E1

Primula minima

E1

E1

Jacobaea carniolica (= Senecio c.)

E1

Phyteuma hemisphaericum

PaT Pooalpinae-Trisetetalia

Poa alpina

Trollius europaeus

E1

E1

Euphrasia picta

Crepis aurea

E1

Trifolium badium

MA Molinio-Arrbenatheretea

Leontodon hispidus

E1

Deschampsia cespitosa

E1

Cerastium fontanum

E1

Taraxacum sect. Ruderalia

E1

Trifolium pratense

E1

Veronica serpyllifolia

LV Loiseleurio-Vaccinietea

Vaccinium gaultherioides

E1 


\begin{tabular}{|c|c|c|c|c|c|c|c|c|c|c|c|c|c|c|c|c|c|}
\hline 8 & 9 & 10 & 11 & 12 & 13 & 14 & 15 & 16 & 17 & 18 & 19 & 20 & 21 & 22 & 23 & Pr. & Fr. \\
\hline 2 & 2 & 1 & + & 1 & . & + & + & . & 1 & . & . & . & . & . & . & 9 & 39 \\
\hline+ & 1 & 1 & + & + & . & . & . & + & 1 & . & . & . & . & + & . & 8 & 35 \\
\hline+ & . & . & . & 1 & + & 3 & 3 & . & . & . & . & . & . & . & + & 6 & 26 \\
\hline . & . & $\cdot$ & . & . & . & . & + & . & . & + & . & + & 1 & 1 & 1 & 6 & 26 \\
\hline . & . & $\cdot$ & $\cdot$ & . & $\cdot$ & $\cdot$ & . & . & . & + & 1 & . & + & + & . & 4 & 17 \\
\hline . & . &. & . & . & . & . &. & . & . & + & . & . & + & + & + & 4 & 17 \\
\hline
\end{tabular}

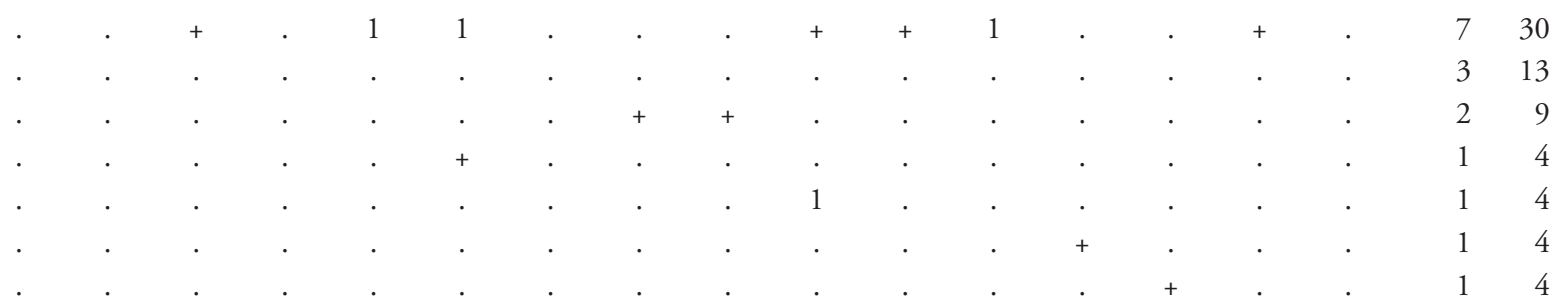

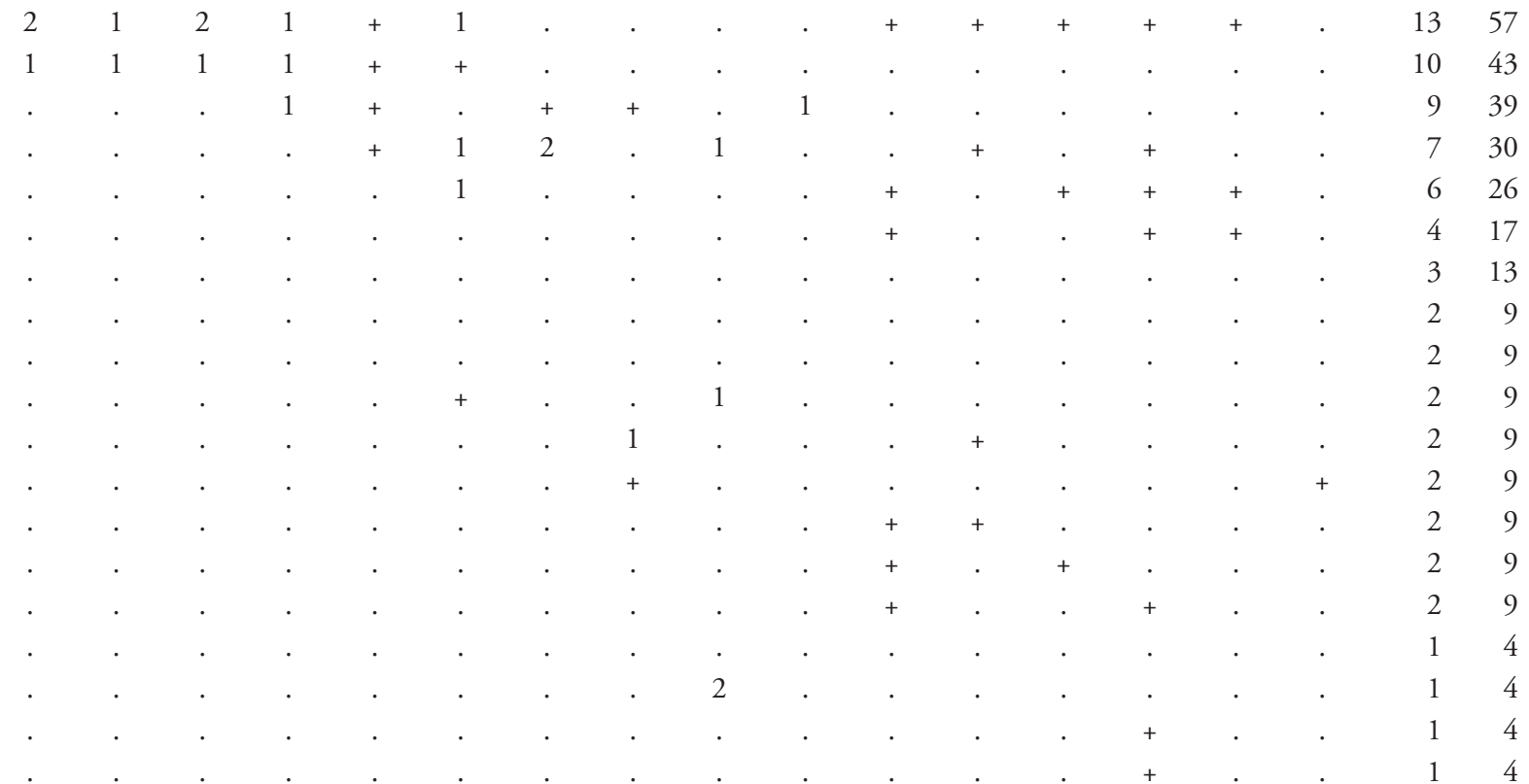

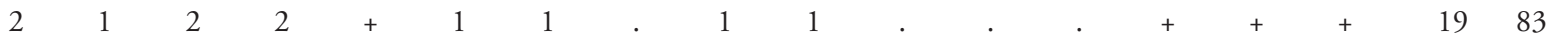

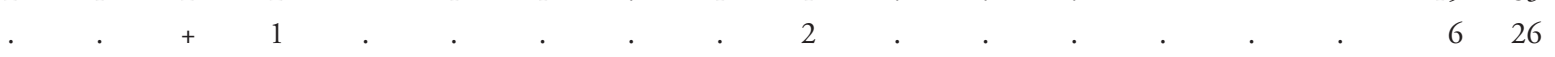

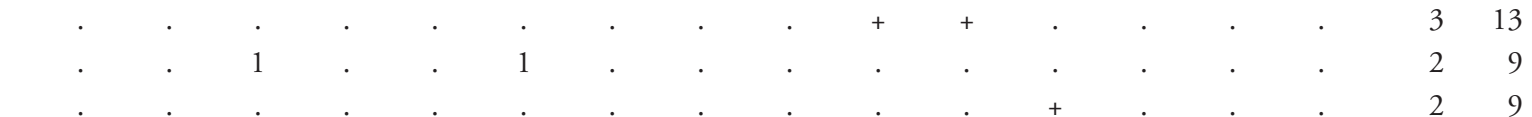

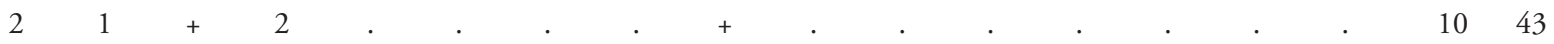

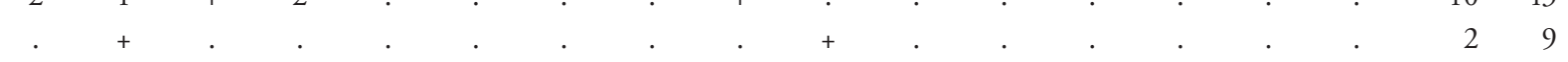

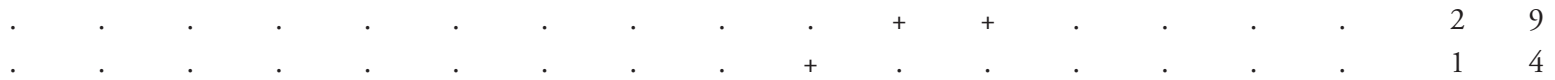

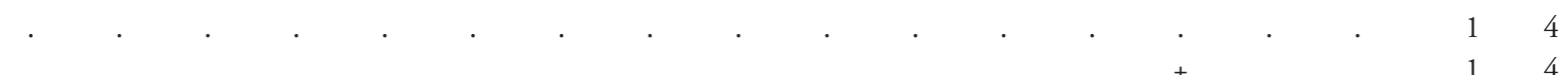


Number of relevé (Zaporedna številka popisa)

$\begin{array}{llllll}1 & 2 & 3 & 4 & 5 & 6\end{array}$

VP

Homogyne alpina

Avenella flexuosa

Calamagrostis villosa

Rhytidiadelphus triquetrus

Vaccinium myrtillus

Peltigera leucophlebia

Rhododendron ferrugineum

OA Oxycocco-Sphagnetea

Carex pauciflora

CF Caricion ferrugineae

Cerastium subtriflorum

Carex ferruginea

Hedysarum hedysaroides

Phleum hirsutum

Gentiana pumila

Trifolium thalii

OE Oxytropido-Elynion

Carex atrata

Antennaria carpatica (incl. subsp. helvetica)

Gentiana nivalis

Lloydia serotina

Arenaria ciliata

Elyna myosuroides (= Carex myosuroides)

CA Caricion austroalpinae

Festuca calva

Cfir Caricion firmae

Silene acaulis

Dryas octopetala

Minuartia sedoides

Veronica aphylla

SV Seslerion coeruleae

Achillea clavenae

Juncus monanthos

Ranunculus carinthiacus

ES

\section{Elyno-Seslerietea}

Polygonum viviparum

Myosotis alpestris

Thymus praecox subsp. polytrichus

Cerastium strictum

Rhinanthus glacialis

Agrostis alpina

Sesleria caerulea

Gentianella anisodonta

Selaginella selaginoides

Aster bellidiastrum

Bartsia alpina

Gentiana verna

Alchemilla exigua

Astragalus penduliflorus

Acinos alpinus (= Calamintha a.)
E1

E1

E1

E0

E1

E0

E2

E1

E1

E1

E1

E1

E1

E1

E1

E1

E1

E1

E1

E1

E1

E1

E1

E1

E1

E1

E1

\begin{tabular}{|lllllll|}
\hline 1 & + & + & $\cdot$ & $\cdot$ & $\cdot$ & $\cdot$ \\
$\mathrm{r}$ & + & $\cdot$ & $\cdot$ & $\cdot$ & $\cdot$ & $\cdot$ \\
. & + &. &. & + &. & $\cdot$ \\
\hline
\end{tabular}

E1

E1

E1

E1

E1

E1

E1

E1

E1

E1

E1

E1

E1

E1

E1 


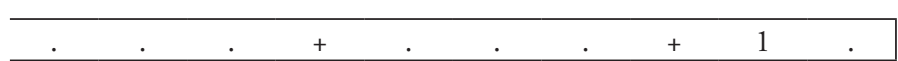


Number of relevé (Zaporedna številka popisa)

\section{1}

\section{2} 3

MuA Mulgedio-Aconitetea

Viola biflora

Geranium sylvaticum

E1

Peucedanum ostruthium

E1

Alchemilla xanthochlora

E1

Veratrum album

E1

Tephroseris crispa

E1

Adenostyles alliariae

E1

Aconitum lycoctonum subsp. ranunculifolium

E1

Epilobium alpestre

E1

E1

BA Betulo-Alnetea

Alnus alnobetula (= A. viridis) E2

Salix waldsteiniana

CD Caricetalia davallianae

Parnassia palustris

E1

MC Montio-Cardaminetea

Saxifraga aizoides

E1

$\mathrm{SH}$ Salicetea herbaceae

Sibbaldia procumbens

E1

Cerastium cerastoides

Gnaphalium supinum

E1

Ranunculus aconitifolius

Salix herbacea

AA Androsacetalia alpinae

ac Sedum alpestre

E1

Veronica alpina

E1

ac

Cardamine resedifolia

E1

$\mathrm{ac}$

Geum reptans

Gentiana bavarica

Androsace alpina

E1

ac

Oxyria digina

Ranunculus glacialis

AC Arabidetalia caeruleae

Salix retusa

Soldanella alpina

E1

Alchemilla fissa

E1

Salix reticulata

Taraxacum sect. Alpina

Arabis caerulea

Carex parviflora

Gnaphalium hoppeanum

Pritzelago alpina subsp. brevicaulis (= Hutchinsia bre.)

Saxifraga androsacea

Soldanella minima

TR Thlaspietea rotundifolii

Festuca nitida

E1

Cirsium spinosissimum

Heliosperma alpestre

Achillea atrata

ac

Epilobium collinum

Saxifraga oppositifolia 


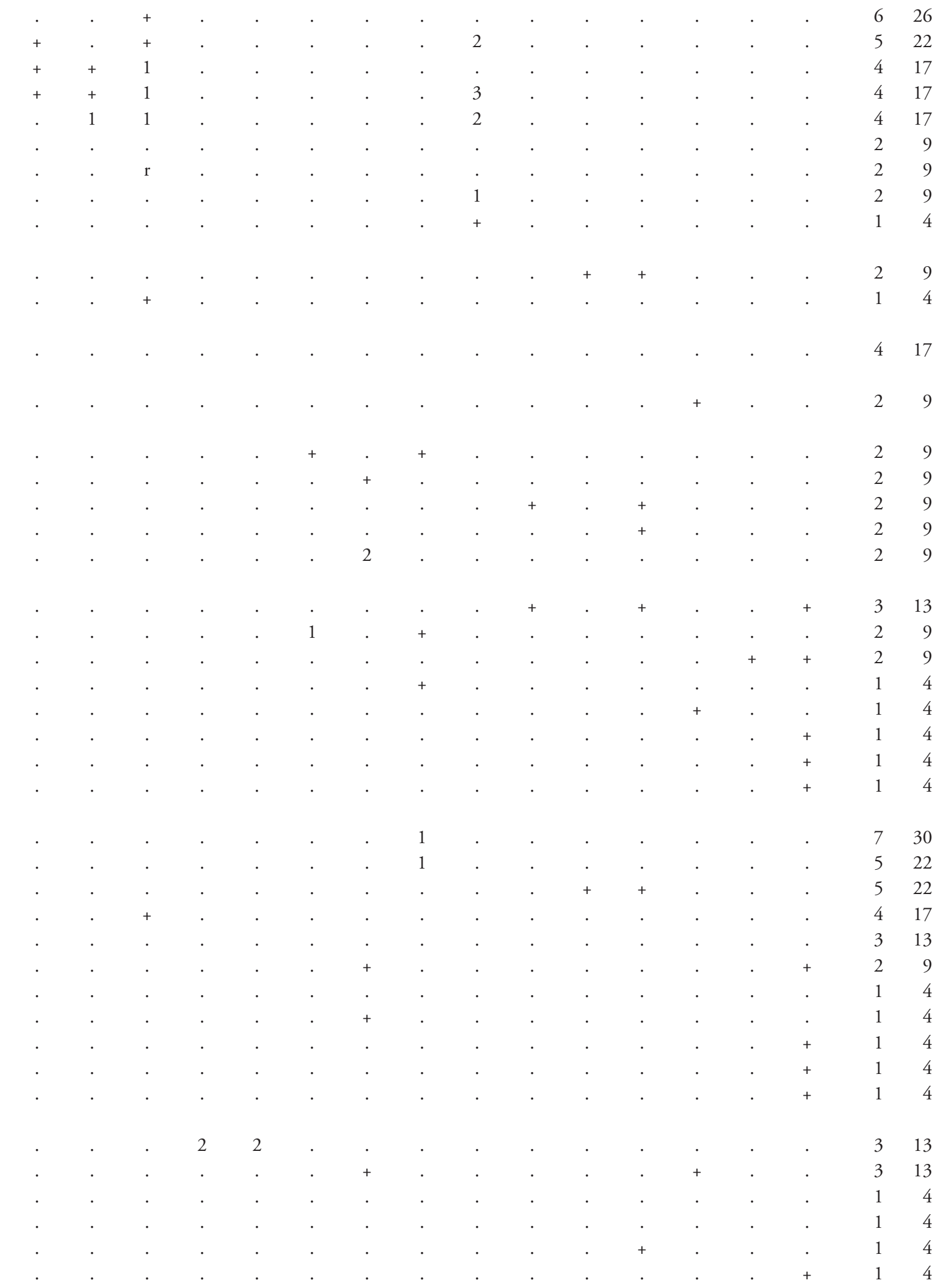




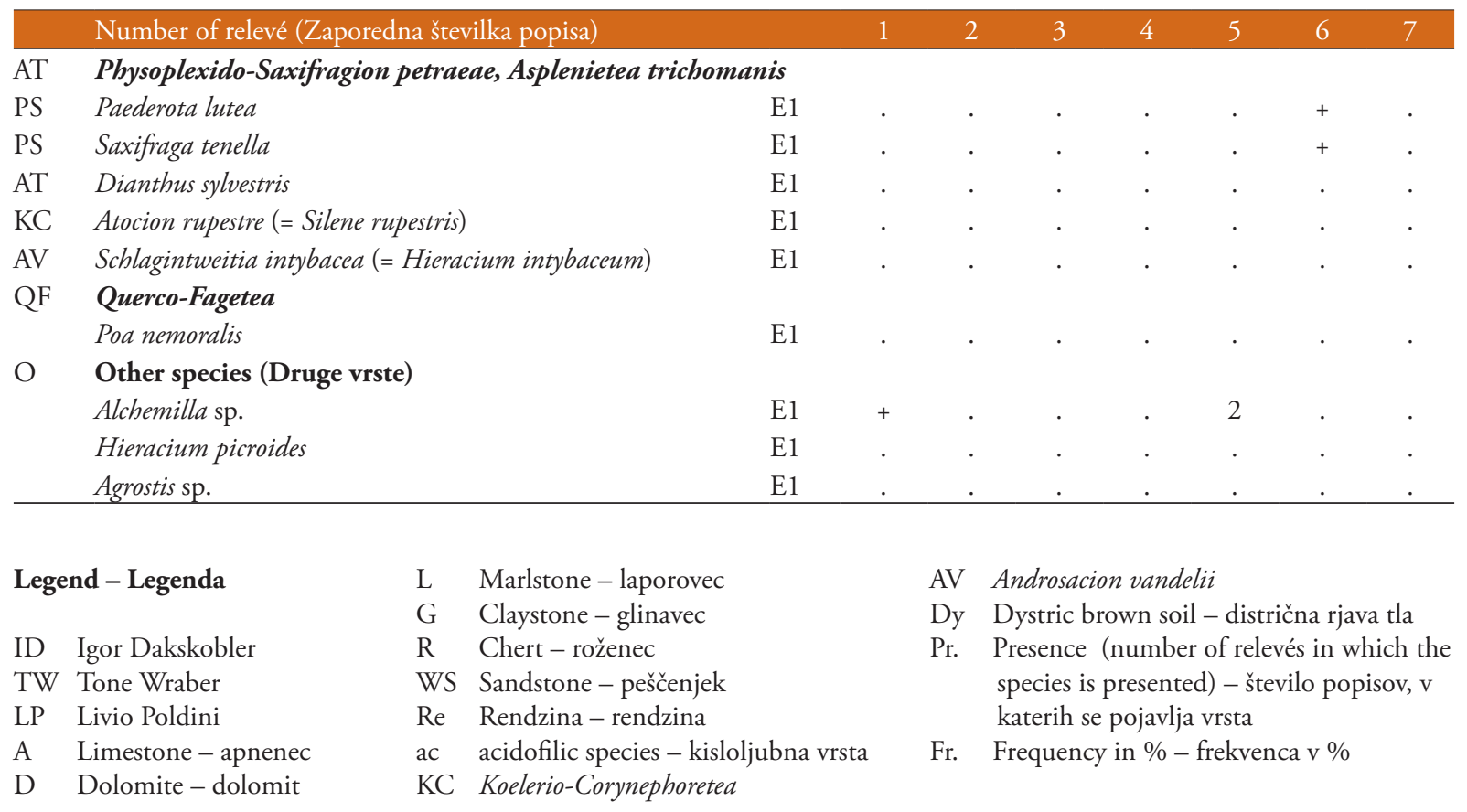

Table 2: Synoptic table of the association Luzuletum alpinopilosae s. lat. in the Alps.

Tabela 2: Sintezna tabela asociacije Luzuletum alpinopilosae s. lat. v Alpah.

\begin{tabular}{|c|c|c|c|c|c|c|c|}
\hline & Successive number (Zaporedna številka) & & 1 & 2 & 3 & 4 & 5 \\
\hline & Number of relevés (Število popisov) & & 15 & 8 & 18 & 10 & 3 \\
\hline & Author of relevés (Avtor popisov) & & TWID & LP & $\mathrm{PH}$ & $\mathrm{CL}$ & $\mathrm{BB}$ \\
\hline \multirow[t]{11}{*}{$\overline{\mathrm{SH}}$} & Salicetea herbaceae & & & & & & \\
\hline & Luzula alpinopilosa & E1 & 100 & 100 & 100 & 100 & 100 \\
\hline & Soldanella pusilla & E1 & 27 & 25 & 72 & 80 & 100 \\
\hline & Sibbaldia procumbens & E1 & 7 & 13 & 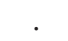 & 40 & . \\
\hline & Gnaphalium supinum & E1 & . & 25 & 67 & 30 & 67 \\
\hline & Salix herbacea & E1 & . & 13 & 67 & 80 & 67 \\
\hline & Cerastium cerastioides & E1 & . & 13 & . & . & 33 \\
\hline & Ranunculus aconitifolius & E1 & . & 13 & . & . & . \\
\hline & Pohlia drumondii & E0 & . & . & . & . & 33 \\
\hline & Polytrichastrum sexangulare & E0 & . & . & . & . & 33 \\
\hline & Kiaeria starkei & E0 & . & . & 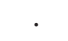 & . & 33 \\
\hline \multirow[t]{11}{*}{$\mathrm{AA}$} & Androsacetalia alpinae & & & & & & \\
\hline & Veronica alpina & E1 & 7 & 13 & & 60 & \\
\hline & Sedum alpestre & E1 & . & 38 & . & . & 33 \\
\hline & Oxyria digyna & E1 & . & 13 & . & 10 & \\
\hline & Cardamine resedifolia & E1 & . & 25 & 33 & . & 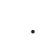 \\
\hline & Gentiana bavarica & E1 & . & 13 & 67 & . & . \\
\hline & Androsace alpina & E1 & . & 13 & . & . & . \\
\hline & Ranunculus glacialis & E1 & . & 13 & . & . & . \\
\hline & Epilobium collinum & E1 & . & 13 & . & . & $\cdot$ \\
\hline & Geum reptans & E1 & . & 13 & . & . & ${ }^{\circ}$ \\
\hline & Veronica alpina & E1 & . & . & 61 & . & 100 \\
\hline
\end{tabular}




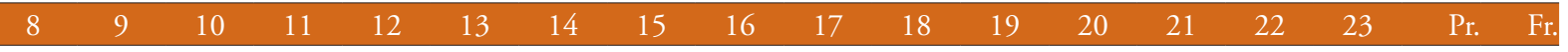

\begin{tabular}{|c|c|c|c|c|c|c|c|c|c|c|c|c|c|c|c|c|}
\hline . & . & . & $\cdot$ & . & . & . & . & . & . & . & . & . & . & . & . & 1 \\
\hline . & . & . & . & . & . & . & . & . & • & . & . & . & . & . & . & 1 \\
\hline . & . & . & . & . & . & . & . & . & . & . & + & . & + & . & . & 2 \\
\hline . & . & . & . & . & . & . & . & . & . & . & . & + & 1 & + & . & 3 \\
\hline . & . & . & . & . & . & . & . & . & . & . & . & . & . & + & . & 1 \\
\hline . & . & . & . & . & • & . & . & . & . & . & . & $\cdot$ & + & . & . & 1 \\
\hline . & . & . & 1 & . & . & . & . & . & . & . & . & . & . & . & . & 3 \\
\hline . & . & . & . & . & . & . & . & . & . & . & . & 2 & + & . & . & 2 \\
\hline . & . & . & . & . & + & . & . & . & . & . & . & . & . & . & . & 1 \\
\hline
\end{tabular}

Successive number (Zaporedna številka)

\section{E1}

Saxifraga seguieri

Saxifraga bryoides

Cerastium uniflorum

Primula latifolia

AC

Arabidetalia caeruleae

Trifolium pallescens

Salix retusa

Salix reticulata

Soldanella alpina

Taraxacum sect. Alpina

Alchemilla fissa

Doronicum glaciale

Carex parviflora

Arabis caerulea

Saxifraga androsace

Hutchinsia alpina s. lat.

Soldanella minima

Gnaphalium hoppeanum

Ranunculus alpestris

Taraxacum carinthiacum

Achillea oxyloba

Potentilla brauneana

Gnaphalium hoppeanum
E1

E1

E1

E1

E1 60

E1 40

E1 27

E1 27

E1 20

E1 20

E1 13

E1 7

E1

E1

E1

E1

E1

E1

E1

E1

E1

E1

\section{5}

100

100

100

33

67 
NS Nardion strictae

Successive number (Zaporedna številka)

Alchemilla glaberima

TR Thlaspietea rotundifolii

Rhodiola rosea

Festuca nitida

Cirsium spinosissimum

Achillea atrata

Heliosperma alpestre

Leucanthemum atratum subsp. halleri

Arabis alpina

Thlaspi minimum

Doronicum grandiflorum

Saxifraga sedoides

Festuca nigrescens

Coeloglossum viride

Agrostis capillaris

Nardus stricta

Gentiana punctata

Campanula barbata

Alchemilla flabellata

E1

1

2

3

3
4

5

Juncetea trifidi

Juncus jacquinii

Anthoxanthum nipponicum

Geum montanum

Campanula scheuchzeri

Leontodon helveticus

Potentilla aurea

Helictotrichon versicolor

Juncus trifidus

Agrostis rupestris

Euphrasia minima

Luzula spicata

Carex curvula

Solidago virgaurea subsp. minuta

Botrychium lunaria

Leucanthemopsis alpina

Hieracium alpinum

Oreochloa disticha

Pulsatilla alpina subsp. austriaca

Festuca cfr. pseudodura

Veronica bellidioides

Veronica fruticans

Phyteuma hemisphaericum

Primula minima

Jacobaea carniolica (= Senecio c.)

Phleum alpinum

Poa variegata

Pedicularis kerneri

E1 53

E1 20

E1 7

E1 7

E1 7

E1

E1

E1

E1

E1

E1 27

E1 20

E1 7

E1 7

E1

E1

E1

E1 73

E1 67

E1 60

E1 53

E1 53

E1 53

E1 27

E1 20

E1 13

E1 13

E1 13

E1 7

E1

E1

E1

E1

E1

E1

E1

E1

E1

E1

E1

E1

E1

E1

E1

E1 13

E1
33

3

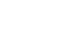

50
67

33

22

Loiseleurio-Vaccinietea

Vaccinium gaultherioides

Carex pauciflora

\begin{tabular}{|c|c|c|c|}
\hline 25 & 22 & 60 & 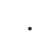 \\
\hline . & 78 & 20 & 67 \\
\hline 75 & 72 & 50 & . \\
\hline 13 & 72 & . & 100 \\
\hline 63 & 61 & 20 & 100 \\
\hline 13 & 50 & 50 & . \\
\hline 38 & 11 & 10 & 67 \\
\hline . & 17 & . & . \\
\hline 50 & 22 & . & 33 \\
\hline . & 44 & 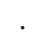 & . \\
\hline . & . & 10 & . \\
\hline 13 & 28 & $\cdot$ & . \\
\hline 38 & . & . & . \\
\hline . & . & . & . \\
\hline 75 & 67 & . & 100 \\
\hline 50 & 6 & . & . \\
\hline 25 & 22 & . & 67 \\
\hline 25 & 17 & . & . \\
\hline 25 & . & . & . \\
\hline 25 & . & . & . \\
\hline 25 & . & . & . \\
\hline 13 & 11 & 20 & 33 \\
\hline 13 & 72 & . & . \\
\hline 13 & . & 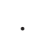 & . \\
\hline . & 61 & 30 & 33 \\
\hline$\cdot$ & . & 10 & . \\
\hline . & . & . & 33 \\
\hline
\end{tabular}

11 
Successive number (Zaporedna številka)

Loiseleuria procumbens

E1

$1 \quad 2 \quad 3$

$\mathrm{OE}$

Oxytropido-Elynion

Carex atrata

E

Antennaria carpatica

E1

Gentiana nivalis

E1 13

Lloydia serotina

E1 13

Arenaria ciliata

E1 7

Elyna myosuroides (Carex myosuroides)

E1

CA Caricion austroalpinae

Koeleria eriostachya

E1 27

Festuca calva

E1 7

CF Caricion ferrugineae

Cerastium subtriflorum

E1 20

Hedysarum hedysaroides

E1 20

Carex ferruginea

E1 13

Phleum hirsutum

E1 13

Gentiana pumila

Trifolium thalii

Festuca violacea

E1

E1

E1

Caricion firmae

Silene acaulis

E1 13

Dryas octopetala

Minuartia sedoides

Veronica aphylla

Festuca quadriflora (F. pumila)

Pedicularis rostratocapitata

E1

E1

E1

E1

E1

SV Seslerion coeruleae

Galium anisophyllum

Potentilla crantzii

Achillea clavennae

Juncus monanthos

Ranunculus carinthiacus

Festuca violacea agg. (F. norica?)

Erigeronn neglectus

$\begin{array}{cccccc}\text { E1 } & 47 & 25 & 28 & . & . \\ \text { E1 } & 33 & . & . & . & . \\ \text { E1 } & 20 & 13 & . & . & . \\ \text { E1 } & 13 & . & . & . & . \\ \text { E1 } & 13 & . & . & 30 & . \\ \text { E1 } & . & . & 22 & . & . \\ \text { E1 } & . & . & . & 10 & .\end{array}$

ES Elyno-Seslerietea

Polygonum viviparum

$\begin{array}{cccccc}\text { E1 } & 80 & 25 & 100 & 50 & 100 \\ \text { E1 } & 47 & . & . & . & . \\ \text { E1 } & 33 & . & . & . & . \\ \text { E1 } & 33 & . & . & . & . \\ \text { E1 } & 27 & . & . & . & . \\ \text { E1 } & 27 & 25 & 50 & 20 & 67 \\ \text { E1 } & 13 & 38 & . & . & . \\ \text { E1 } & 13 & 13 & . & . & . \\ \text { E1 } & 13 & . & . & . & . \\ \text { E1 } & 13 & . & 33 & . & . \\ \text { E1 } & 7 & 13 & . & . & . \\ \text { E1 } & 7 & . & 67 & 20 & . \\ \text { E1 } & 7 & . & 44 & . & . \\ \text { E1 } & 7 & . & 33 & . & . \\ \text { E1 } & 7 & . & . & 10 & . \\ \text { E1 } & 7 & . & . & . & .\end{array}$




\begin{tabular}{|c|c|c|c|c|c|c|c|}
\hline & Successive number (Zaporedna številka) & & 1 & 2 & 3 & 4 & 5 \\
\hline & Arenaria biflora & E1 & . & 50 & . & . & . \\
\hline & Astragalus penduliflorus & E1 & . & 13 & . & . & . \\
\hline & Acinos alpinus (Clinopodium alpinum) & E1 & . & 13 & . & . & . \\
\hline & Ligusticum mutellina & E1 & . & . & 61 & . & 100 \\
\hline & Ranunculus montanus & E1 & . & . & 50 & . & 100 \\
\hline & Carex sempervirens & E1 & . & . & 17 & . & . \\
\hline \multirow[t]{2}{*}{$\mathrm{CD}$} & Caricetalia davallianae & & & & & & \\
\hline & Parnassia palustris & E1 & 27 & . & . & . & . \\
\hline \multirow[t]{5}{*}{$\mathrm{MC}$} & Montio-Cardaminetea & & & & & & \\
\hline & Saxifraga aizoides & E1 & 7 & 13 & 61 & . & . \\
\hline & Arabis subcoriacea (A. soyeri) & E1 & . & . & 56 & . & . \\
\hline & Saxifraga stellaris & E1 & . & . & 33 & . & 67 \\
\hline & Alchemilla glabra & E1 & . & . & . & 20 & . \\
\hline \multicolumn{8}{|c|}{ MuA Mulgedio-Aconitetea } \\
\hline & Rumex arifolius & E1 & 40 & 25 & . & . & . \\
\hline & Viola biflora & E1 & 40 & . & . & . & . \\
\hline & Geranium sylvaticum & E1 & 33 & . & . & . & . \\
\hline & Alchemilla xanthochlora & E1 & 27 & . & . & . & . \\
\hline & Peucedanum ostruthium & E1 & 27 & . & . & . & . \\
\hline & Veratrum album & E1 & 27 & . & . & . & . \\
\hline & Aconitum lycoctonum subsp. ranunculifolium & E1 & 13 & . & . & . & . \\
\hline & Adenostyles alliariae & E1 & 13 & . & . & 10 & 33 \\
\hline & Tephroseris crispa & E1 & 13 & . & . & . & . \\
\hline & Epilobium alpestre & E1 & 7 & . & . & . & . \\
\hline \multirow[t]{3}{*}{$\mathrm{BA}$} & Betulo-Alnetea & & & & & & \\
\hline & Salix waldsteiniana & E2 & 7 & . & . & . & . \\
\hline & Alnus alnobetula (= A. viridis) & $\mathrm{E} 2$ & . & 25 & . & . & . \\
\hline \multirow[t]{7}{*}{$\mathrm{PaT}$} & Poo alpinae-Trisetetalia & & & & & & \\
\hline & Poa alpina & E1 & 100 & 50 & 100 & 70 & 33 \\
\hline & Phleum rhaeticum & E1 & 53 & . & . & . & . \\
\hline & Trollius europaeus & E1 & 40 & . & . & . & . \\
\hline & Crepis aurea & E1 & 13 & . & . & . & . \\
\hline & Euphrasia picta & $\mathrm{E} 1$ & 7 & 25 & . & . & . \\
\hline & Trifolium badium & E1 & 7 & 13 & 44 & . & . \\
\hline \multirow[t]{7}{*}{ MA } & Molinio-Arrbenatberetea & & & & & & \\
\hline & Leontodon hispidus & $\mathrm{E} 1$ & 60 & 13 & . & 10 & . \\
\hline & Deschampsia cespitosa & E1 & 13 & . & 78 & . & . \\
\hline & Trifolium pratense & E1 & 7 & . & 22 & . & . \\
\hline & Taraxacum sect. Ruderalia & E1 & 7 & . & . & . & . \\
\hline & Cerastium fontanum & $\mathrm{E} 1$ & . & 25 & . & . & . \\
\hline & Veronica serpyllifolia & E1 & . & 13 & . & . & . \\
\hline \multirow[t]{2}{*}{ OA } & Oxycocco-Sphagnetea & & & & & & \\
\hline & Carex pauciflora & E1 & . & 13 & . & . & . \\
\hline \multirow[t]{8}{*}{ VP } & Vaccinio-Piceetea & & & & & & \\
\hline & Homogyne alpina & E1 & 13 & 25 & 67 & 40 & . \\
\hline & Rhytidiadelphus triquetrus & E1 & 13 & . & . & . & . \\
\hline & Vaccinium myrtillus & E1 & 7 & . & 6 & . & . \\
\hline & Peltigera leucophlebia & E1 & 7 & . & . & . & . \\
\hline & Avenella flexuosa & E1 & . & 50 & 33 & . & . \\
\hline & Calamagrostis villosa & E1 & . & 38 & . & . & . \\
\hline & Rhododendron ferrugineum & E2 & . & 13 & 22 & . & . \\
\hline
\end{tabular}




\begin{tabular}{|c|c|c|c|c|c|c|c|}
\hline & Successive number (Zaporedna številka) & & 1 & 2 & 3 & 4 & 5 \\
\hline & Huperzia selago & E1 & . & . & 33 & . & 33 \\
\hline & Pleurozium schreberi & E0 & . & . & 11 & . & . \\
\hline & Luzla sieberi & E1 & . & . & . & 10 & . \\
\hline & Hyleucomium splendens & E0 & . & . & . & $\cdot$ & 33 \\
\hline \multirow[t]{2}{*}{ QF } & Querco-Fagetea & & & & & & \\
\hline & Poa nemoralis & E1 & . & 13 & . & . & . \\
\hline PS & Physoplexido-Saxifragion petraeae, Asplenietea th & & & & & & \\
\hline PS & Paederota lutea & E1 & 7 & . & . & . & . \\
\hline PS & Saxifraga tenella & E1 & 7 & . & . & $\cdot$ & . \\
\hline $\mathrm{KC}$ & Atocion rupestre (= Silene rupestris) & E1 & . & 38 & . & . & . \\
\hline AT & Dianthus sylvestris & E1 & . & 25 & . & . & . \\
\hline AV & Schlagintweitia intybacea (= Hieracium intybaceum) & E1 & . & 13 & . & . & . \\
\hline \multirow[t]{5}{*}{$\mathrm{O}$} & Other species (Druge vrste) & & & & & & \\
\hline & Alchemilla sp. & E1 & 20 & . & . & . & . \\
\hline & Agrostis sp. & E1 & 7 & . & . & $\cdot$ & . \\
\hline & Hieracium picroides & E1 & . & 25 & . & . & . \\
\hline & Salix breviserrata & E2 & . & . & . & 10 & . \\
\hline \multirow[t]{25}{*}{ ML } & Mosses and lichens (Mahovi in lišaji) & & & & & & \\
\hline & Cladonia pyxidata & E0 & . & . & 22 & . & 33 \\
\hline & Solorina crocea & E0 & . & . & 22 & . & 33 \\
\hline & Cetraria islandica & E0 & . & . & 33 & . & . \\
\hline & Polytrichastrum sexangulare & E0 & . & . & 11 & $\cdot$ & . \\
\hline & Cladonia mitia & E0 & . & . & 6 & . & . \\
\hline & Cladonia furcata & E0 & . & . & 6 & . & . \\
\hline & Desmatodon latifolius & E0 & . & . & . & . & 100 \\
\hline & Bartramia ithyphylla & E0 & . & . & . & . & 67 \\
\hline & Sciuro-hypnum reflexum & E0 & . & . & . & . & 67 \\
\hline & Nardia scalaris & E0 & . & . & . & . & 67 \\
\hline & Nardia geoscyphus & E0 & . & . & . & . & 67 \\
\hline & Anthelia julacea & E0 & . & . & . & . & 67 \\
\hline & Blepharostoma trichophyllum & E0 & . & . & . & . & 67 \\
\hline & Lephozia ventricosa & E0 & . & . & . & . & 67 \\
\hline & Sanionia uncinata & E0 & . & . & . & . & 67 \\
\hline & Polytrichum juniperinum & E0 & . & . & . & . & 33 \\
\hline & Polytrichum piliferum & E0 & . & . & . & . & 33 \\
\hline & Ditrichum flexicaule & E0 & . & . & . & . & 33 \\
\hline & Plagiochila asplenioides & E0 & . & . & . & . & 33 \\
\hline & Brachythecium albicans & E0 & . & . & . & . & 33 \\
\hline & Brachythecium glareosum & E0 & . & . & . & . & 33 \\
\hline & Gymnomitrion varians & E0 & . & . & . & . & 33 \\
\hline & Racomitrium canescens & E0 & . & . & . & . & 33 \\
\hline & Peltigera aphtosa & E0 & . & . & . &. & 33 \\
\hline
\end{tabular}

\section{Legend - Legenda}

1 Junco jacquinii-Luzuletum alpinopilosae, Julian Alps, Slovenia, I. Dakskobler, T. Wraber, this article

2 Junco jacquini-Luzuletum alpinopilosae, Carnic Alps, L. Poldini, this article

3 Luzuletum alpinopilosae salicetosum retusae, Tappenkars, Austra, Heiselmayer (1982)
4 Taraxaco carinthiaci-Luzuletum alpinopilosae, Dolomites, Feltre, Lasen (1982)

5 Luzuletum spadiceae, Central Alps, Braun-Blanquet in Braun-Blanquet et Jenny (1926)

KC Koelerio-Corynephoretea

AV Androsacion vandelii 
Table 3: Groups of diagnostic species in the communities with dominant Luzula alpinopilosa in the Alps (relative frequencies).

Tabela 3: Skupine diagnostičnih vrst v združbah s prevladujočo vrtso Luzula alpinopilosa v Alpah (relativne frekvence).

\begin{tabular}{|c|c|c|c|c|c|}
\hline Successive number (Zaporedna številka) & 1 & 2 & 3 & 4 & 5 \\
\hline Number of relevés (Število popisov) & 15 & 8 & 18 & 10 & 3 \\
\hline Author of relevés (Avtor popisov) & TWID & LP & $\mathrm{PH}$ & CL & $\mathrm{BB}$ \\
\hline Salicetum herbaceae & 5.69 & 10.0 & 9.75 & 19.3 & 13.7 \\
\hline Androsacetalia alpinae & 0.3 & 7.65 & 5.13 & 4.09 & 15.7 \\
\hline Arabidetalia caeruleae & 8.66 & 8.84 & 12.0 & 31.0 & 3.92 \\
\hline Thlaspietea rotundifolii & 3.98 & 1.24 & 5.48 & 5.26 & 0 \\
\hline Nardion strictae & 2.56 & 5.07 & 1.75 & 0 & 0 \\
\hline Juncetea trifidi & 19.9 & 30.7 & 23.4 & 16.4 & 18.6 \\
\hline Loiseleurio-Vaccinietea & 0.57 & 0.65 & 1.4 & 0 & 0 \\
\hline Vaccinio-Piceetea & 1.71 & 6.26 & 5.48 & 2.92 & 1.94 \\
\hline Oxycocco-Sphagnetea & 0 & 0.65 & 0 & 0 & 0 \\
\hline Oxytropido-Elynion & 3.41 & 1.29 & 0 & 0.58 & 0 \\
\hline Caricion austroalpinae & 1.41 & 0 & 0 & 0 & 0 \\
\hline Caricion ferrugineae & 3.41 & 0 & 0 & 3.51 & 0.97 \\
\hline Caricion firmae & 1.71 & 0.65 & 3.76 & 1.75 & 0.97 \\
\hline Seslerion coeruleae & 5.41 & 1.89 & 1.59 & 2.34 & 0 \\
\hline Elyno-Seslerietea & 14.5 & 9.44 & 14.5 & 5.85 & 10.8 \\
\hline Caricetalia davallianae & 1.15 & 0 & 0 & 0 & 0 \\
\hline Montio-Cardaminetea & 0.28 & 0.65 & 4.78 & 1.17 & 1.97 \\
\hline Mulgedio-Aconitetea, Betulo-Alnetea & 10.5 & 2.48 & 0 & 0.58 & 0.97 \\
\hline Poo alpinae-Trisetetalia & 9.38 & 4.37 & 4.59 & 4.09 & 0.97 \\
\hline Molinio-Arrhenatheretea & 3.7 & 2.53 & 3.19 & 0.58 & 0 \\
\hline Querco-Fagetea & 0 & 0.65 & 0 & 0 & 0 \\
\hline Physoplexido-Saxifragion petraeae, Asplenietea trichomanis & 0.55 & 3.78 & 0 & 0 & 0 \\
\hline Other species (Druge vrste) & 1.14 & 1.24 & 0 & 0.58 & 0 \\
\hline Mosses and lichens (Mahovi in lišaji) & 0 & 0 & 3.19 & 0 & 29.4 \\
\hline Total (Skupaj) & 100.0 & 100.0 & 100.0 & 100.0 & 100.0 \\
\hline
\end{tabular}

\section{Legend - Legenda}

1 Junco jacquinii-Luzuletum alpinopilosae, Julian Alps, Slovenia, I. Dakskobler, T. Wraber, this article

2 Junco jacquini-Luzuletum alpinopilosae, Carnic Alps, L. Poldini, this article

3 Luzuletum alpinopilosae salicetosum retusae, Tappenkars, Austra, Heiselmayer (1982)

4 Taraxaco carinthiaci-Luzuletum alpinopilosae, Dolomites, Feltre, Lasen (1982)

5 Luzuletum spadiceae, Central Alps, Braun-Blanquet in Braun-Blanquet et Jenny (1926) 